RENATA MARTINS DA SILVA PRADO

EFEITOS CARDIOVASCULARES DA MEPIVACAÍNA COM EPINEFRINA SEGUIDA DE HIALURONIDASE:

ENSAIO DUPLO-CEGO CONTROLADO EM CIRURGIAS BILATERAIS DE TERCEIROS MOLARES INFERIORES 


\section{Renata Martins da Silva Prado}

Efeitos cardiovasculares da mepivacaína com epinefrina seguida de hialuronidase: ensaio duplo-cego controlado em cirurgias bilaterais de terceiros molares inferiores

Dissertação apresentada à Faculdade de Odontologia da Universidade de São Paulo, para obter o título de Mestre pelo Programa de Pós-Graduação em Odontologia.

Área de Concentração: Clínica Integrada

Orientadora: Prof ${ }^{\mathrm{a}}$.Dra ${ }^{\mathrm{a}}$. Maria Aparecida

Borsatti

São Paulo 


\section{FOLHA DE APROVAÇÃO}

Prado RMS. Efeitos cardiovasculares da mepivacaína com epinefrina seguida de hialuronidase: ensaio duplo-cego controlado em cirurgias bilaterais de terceiros molares inferiores [Dissertação de Mestrado]. São Paulo: Faculdade de Odontologia da USP; 2007.

São Paulo, /2007

\section{Banca Examinadora}

1) $\operatorname{Prof}(a) \cdot \operatorname{Dr}(a)$

Titulação:

Julgamento:

Assinatura:

2) $\operatorname{Prof}(a) \cdot \operatorname{Dr}(a)$.

Titulação:

Julgamento:

Assinatura:

3) $\operatorname{Prof}(a) \cdot \operatorname{Dr}(a)$.

Titulação:

Julgamento: Assinatura: 


\section{DEDICATÓRIA}

Aos meus pais Terezinha e Edevaldo que primeiro me ensinaram a importância do estudo e, por ele me deram todas as oportunidades. Depois, falaram-me de honradez e honestidade, exemplificando pra isso, todos os dias em nossa casa. Mais recentemente, me falaram sobre a importância do trabalho, que me acostumei a vê-los realizar diariamente. Algum tempo se passou, e continuam me ensinando as coisas mais importantes da vida e, pra isso, sempre, me dando todas as ferramentas. Vocês são meu Porto Seguro. Obrigada.

Ao meu irmão e ídolo Júnior: olhando diariamente pra você, desde muito pequena, nasceu a vontade de ir sempre mais, pra tentar chegar mais perto do que você sempre foi: o melhor.

Ao meu marido Gustavo que desde nosso primeiro encontro me ensina tudo de mais interessante que há na vida. E sempre com carinho, e paciência, e amor, e atenção, e sempre, e tanto. 


\section{AGRADECIMENTO ESPECIAL}

À minha orientadora Prof ${ }^{\mathrm{a}}$. Dr ${ }^{\mathrm{a}}$. Maria Aparecida Borsatti, por tudo que me ensinou, orientou e mostrou. Por tantas oportunidades, nunca vou conseguir agradecer. 


\section{AGRADECIMENTOS}

Ao Prof. Dr. Nicolau Tortamano pela lição e oportunidade.

Ao Prof. Dr. Rodney Garcia Rocha por se fazer admirar e me fazer continuar.

Ao Prof. Dr. Flávio Eduardo Guillin Perez que primeiro me orientou e me estimulou a continuar.

À Prof ${ }^{\mathrm{a}}$. Dr ${ }^{\mathrm{a}}$. Sibele Sarti Penha, por toda ajuda, sempre e em qualquer momento.

Aos Professores da Disciplina de Clínica Integrada da FOUSP por todos ensinamentos, opiniões e sugestões que foram muito importantes para o meu crescimento profissional.

Aos Profs. Drs. Miriam Lacalle Turbino e Giulio Gavini pela ajuda na elaboração e interpretação da análise estatística.

Às secretárias Vilma, Vera e Regina que só fazem ajudar. Obrigada por tudo.

Ao Maurício, colega de pós-graduação, que fez nascer uma amizade e admiração gigantescas e sempre agiu como se não houvesse uma distância profissional enorme entre nós. Nunca vou deixar de aprender algo com você, a cada hora em que convivemos. Obrigada por toda ajuda, também nesse trabalho.

À Anna e Mayara, também colegas de pós-graduação, pelo convívio e trabalho em conjunto.

Aos meus colegas de pós-graduação: Alexandre, Andréia, Carina, Endrigo, Estevam, Irineu, Kazue, Leopoldo, Marcelo pelo convívio, amizade e companheirismo.

Às bibliotecárias Telma, Vânia, Lúcia, Suely e Gláuci pela ajuda nas pesquisas e na finalização da dissertação. 
Aos meus melhores amigos: Carolina, Karina, Thaís e Evandro com quem convivo e continuo aprendendo todos os dias desde os tempos da faculdade.

Aos pacientes que confiaram em mim e me ofereceram sua saúde, expectativa e paciência.

À APSEN FARMACÊUTICA SIA pelo fornecimento da hialuronidase.

A CAPES, pelo fomento à pesquisa.

A todos que estiveram presentes, em algum momento, me ajudando, incentivando e colaborando para a realização deste trabalho. 
"Pasmo sempre quando acabo qualquer coisa. Pasmo e desolo-me.

O meu instinto de perfeição deveria inibir-me de acabar; deveria inibir-me até de dar começo. Mas distraio-me e faço. O que consigo é um produto, em mim, não de uma aplicação de vontade, mas de uma cedência dela. Começo porque não tenho força pra pensar; acabo porque não tenho alma para suspender.

Este livro é a minha cobardia"

Fernando Pessoa 
Prado RMS. Efeitos cardiovasculares da mepivacaína com epinefrina seguida de hialuronidase: ensaio duplo-cego controlado em cirurgias bilaterais de terceiros molares inferiores [Dissertação de Mestrado]. São Paulo: Faculdade de Odontologia da Universidade de São Paulo; 2007.

\section{RESUMO}

O Objetivo deste estudo controlado e duplo-cego foi avaliar os efeitos cardiovasculares induzidos pelo bloqueio pterigomandibular com o anestésico local cloridrato de mepivacaína $2 \%$, associado à epinefrina, seguido da injeção de hialuronidase 75 UTR ou placebo, antes da regressão do efeito anestésico, para realização de cirurgia de terceiros molares inferiores bilaterais e simétricos, em 20 pacientes. Os parâmetros cardiovasculares Pressão Arterial Sistólica (PS), Diastólica (PD), Média (PM) e Freqüência Cardíaca ( $F C)$ foram monitorados pelos métodos oscilométrico e fotopletismográfico, em 12 etapas. A hialuronidase injetada isoladamente depois do anestésico local $(A L)$ não induziu alterações de PS, PD, PM e FC significativas $(p>0,01)$ comparada ao placebo. O uso do AL seguido de hialuronidase injetada isoladamente antes da regressão do efeito anestésico mostrou-se segura para esta dose e via de administração.

Palavras-Chave: Anestésicos Locais - Odontologia; Mepivacaína; Hialuronogluconaminidase; Sistema Cardiovascular 
Prado RMS. Cardiovascular effects of mepivacaine with epinephrine followed by hyaluronidase: a double-blind controlled trial in bilateral lower third molar surgery [Dissertação de Mestrado]. São Paulo: Faculdade de Odontologia da Universidade de São Paulo; 2007.

\section{ABSTRACT}

The purpose of this controlled and double-blind trial was to evaluate cardiovascular effects induced by pterigomandibular block of local anesthetic (LA) $2 \%$ mepivacaine with epinephrine, followed by injection of hyaluronidase 75 IU or placebo (solvent) before the regression of the anesthetic effect, on symmetric bilateral lower third molar surgery in 20 outpatients. The cardiovascular parameters systolic (SP), diastolic (DP) and mean (MP) pressures and heart rate (HR) were monitored by oscillometric and photopletismographic methods in 12 clinical steps during the procedure. The plain hyaluronidase injected after LA didn't induce significant SP, DP, MP and HR changes ( $p>0.01$ ) compared to placebo. The use of LA followed by plain hyaluronidase injected before the regression of anesthetic effects showed to be safe for this dose and route of administration.

Keywords: Local Anesthetics - Dentistry; Mepivacaine; Hyaluronoglicosaminidase; Cardiovascular System 


\section{LISTA DE ILUSTRAÇÕES}

Figura 2.1- Estrutura do ácido hialurônico. .26

Figura 2.2- Tetrassacarídeo formado pela hialuronidase de testículo bovino

Figura 4.1- Frascos codificados com solução de hialuronidase ou água destilada preparadas e envasadas em frascos de $1,0 \mathrm{~mL}$ pela Apsen Farmacêutica S/A

Figura 4.2- Solução de hialuronidase e água destilada sendo aspiradas para o tubete anestésico local vazio.

Figura 4.3- Pulptest Vitality Scanner Model $2005^{\mathrm{TM}}$ 44

Figura 4.4- Monitor Scholar ${ }^{\circledR}$ II - NIBP (Criticare Syst. Inc., USA). 44

Figura 4.5- Monitoração dos parâmetros cardiovasculares dos pacientes. 49

Quadro 4.1- Composição de 1,0mL de solução anestésica. 41

Quadro 4.2- Composição de 1,0mL de solução de hialuronidase 41

Quadro 4.3- Composição de 1,0mL de placebo. .42

Gráfico 5.1- Valores médios das variáveis cardiovasculares obtidos da mepivacaína com epinefrina seguida de hialuronidase.

Gráfico 5.2- Valores médios das variáveis cardiovasculares obtidos da mepivacaína com epinefrina seguida de placebo

Gráfico 5.3- Valores médios da Pressão Arterial Sistólica. .55

Gráfico 5.4- Valores médios da Pressão Arterial Diastólica. 
Gráfico 5.5- Valores médios da Pressão Arterial Média.

Gráfico 5.6- Valores médios da Freqüência Cardíaca. .56

Tabela 5.1- Média aritmética e desvio padrão dos dados demográficos. 53

Tabela 5.2- Valores da média aritmética e desvio padrão para a duração dos atos cirúrgicos 


\section{LISTA DE SÍMBOLOS}

$\begin{array}{ll}\% & \text { porcentagem } \\ p & \text { probabilidade } \\ \text { тм } & \text { Trade marked } \\ \circledR & \text { Marca registrada } \\ \mathrm{C}^{14} & \text { isótopo de carbono } \\ \circ & \text { grau } \\ \alpha & \text { alfa } \\ \beta & \text { beta } \\ \cdot & \text { minuto }\end{array}$




\section{LISTA DE ABREVIATURAS E SIGLAS}

\begin{tabular}{|c|c|}
\hline ADA & American Dental Association \\
\hline $\mathrm{AL}$ & anestésico local \\
\hline ASA & American Society of Anesthesiologists \\
\hline ASA I & paciente saudável e normal, de acordo com o índice da ASA \\
\hline bpm & batimentos por minuto \\
\hline $\mathrm{C}_{\max }$ & concentração máxima \\
\hline Co & company \\
\hline ECG & eletrocardiograma \\
\hline FC & freqüência cardíaca \\
\hline FOUSP & Faculdade de Odontologia da Universidade de São Paulo \\
\hline h & hora \\
\hline $\mathrm{Hg}$ & mercúrio \\
\hline IMC & índice de massa corpórea $\left(\mathrm{Kg} / \mathrm{m}^{2}\right)$ \\
\hline Inc. & incorporation \\
\hline $\mathrm{Kg}$ & quilograma \\
\hline L & litro \\
\hline LA & local anaesthetic \\
\hline $\mathrm{mg}$ & miligrama \\
\hline $\min$ & minuto \\
\hline $\mathrm{mL}$ & mililitro \\
\hline $\mathrm{mm}$ & milímetro \\
\hline $\mathrm{mm} \mathrm{Hg}$ & milímetro de mercúrio \\
\hline
\end{tabular}




\begin{tabular}{|c|c|}
\hline $\mathrm{m}^{2}$ & metro quadrado \\
\hline$n$ & tamanho da amostra \\
\hline$n^{0}$ & número \\
\hline PAD & pressão arterial sistólica \\
\hline PAS & pressão arterial diastólica \\
\hline PM & pressão arterial média \\
\hline qsp & quantidade suficiente para \\
\hline $\mathrm{R}$ & rectrus ou dextrógiro \\
\hline S & segundos \\
\hline S & sinister ou levógiro \\
\hline S/A & Sociedade Anônima \\
\hline SCV & sistema cardiovascular \\
\hline SNC & sistema nervoso central \\
\hline $\mathrm{T}_{\max }$ & tempo para atingir $\mathrm{Cmax}$ \\
\hline UI & unidade internacional \\
\hline USA & United States of America \\
\hline UTR & unidade de turbidade reduzida \\
\hline$\mu \mathrm{g}$ & micrograma $\left(10^{-6}\right.$ gramas $)$ \\
\hline
\end{tabular}




\section{SUMÁRIO}

p.

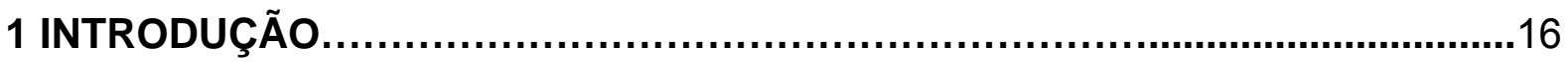

2 REVISÃO DA LITERATURA...................................................... 19

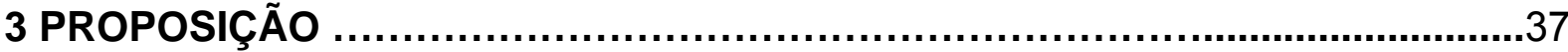

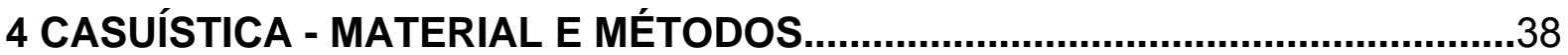

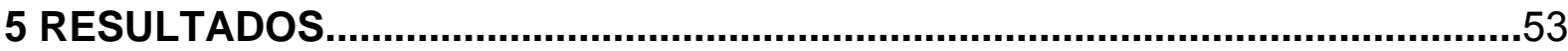

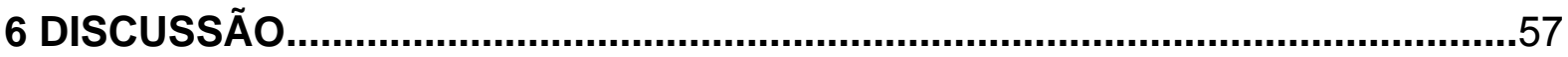

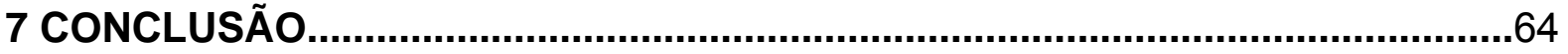

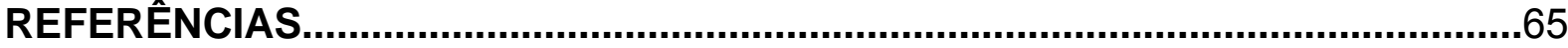

APÊNDICES

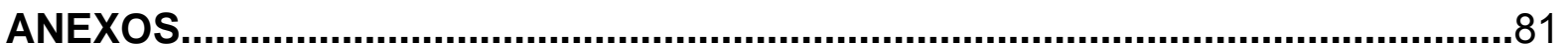




\section{INTRODUÇÃO}

Um dos adjuvantes mais utilizados em associação ao anestésico local (AL) é o vasoconstritor adrenalina, indicado em diversas técnicas anestésicas, para contrapor o efeito vasodilatador inerente à maioria dos agentes AL. Essa interação permite que a base anestésica permaneça no sítio de ação por mais tempo, pois ao diminuir o calibre dos vasos sanguíneos promove lentidão na absorção, o que induz maior duração de ação, melhora na eficácia e redução da toxicidade do AL; além disso, promove hemostasia (CHAN; KARMAKAR; CHUI, 2002). A adrenalina é o mais potente vasoconstritor em associação aos $\mathrm{AL}$, mas também é o que induz efeitos cardiovasculares mais intensos em elevadas concentrações, como aumento da pressão arterial sistólica, taquicardia e queda da pressão diastólica (NAFTALIN; YAGIELA, 2002). Esses efeitos sistêmicos também são comuns aos outros vasoconstritores adrenérgicos noradrenalina, levonordefrina e felinefrina, porém em menor intensidade (BRUNO et al., 1987; CHAN; KARMAKAR; CHUI, 2002; MALAMED, 2001; NAFTALIN; YAGIELA, 2002). Já o vasoconstritor não-adrenérgico felipressina possui reduzidos efeitos sistêmicos, atividade vasoconstritora menos intensa e não está disponível em todos os países (MALAMED, 2001).

Nos pacientes cardiopatas ou hipertensos que fazem uso de medicações que contra-indique o uso de anestésico com vasoconstritores adrenérgicos devido ao risco de interação medicamentosa ou quando não há disponibilidade de anestésico local com felipressina, as opções de uso são os anestésicos locais de ação intermediária sem vasoconstritor. Contudo, sua duração de ação é insuficiente para a realização de procedimentos de duração prolongada, sem que haja dor. Também 
está contra-indicado nesses pacientes anestésico local de ação prolongada bupivacaína, devido à sua maior cardiotoxicidade (BORSATTI; TAKAOKA; 2007).

Dos adjuvantes alternativos aos vasoconstritores que propiciam benefício na prática da anestesia regional utilizado para melhorar a eficácia clínica, tem-se a hialuronidase, uma enzima usada como agente difusor. É muito utilizada em oftalmologia, injetada concomitantemente ao anestésico local.

Essas vantagens foram contestadas por Ridenour et al. (2001) para uso em odontologia, por não melhorar o índice de sucesso da anestesia e induzir dor e trismo no pós-operatório. Provavelmente estes efeitos foram devido à hialuronidase ter facilitado a difusão do anestésico local, que estava em alta concentração nesse momento, para os tecidos adjacentes.

Entretanto, no estudo laboratorial de Borsatti et al. (2004) e clínico de Horliana (2006) foi testada a hipótese de que a hialuronidase injetada antes do término do efeito anestésico local prolonga a duração de ação. Dado o significativo aumento da duração do bloqueio sensitivo observado nesses estudos, vislumbra-se a possibilidade de uma futura utilização da hialuronidase ser injetada antes do término da anestesia local em pacientes cardiopatas, com a finalidade de prolongar a duração de ação e reduzir a necessidade de complementação anestésica.

Essa combinação poder ser usada em procedimentos de longa duração como cirurgias para a retirada de terceiros molares, cirurgias para colocação de implantes e alguns procedimentos endodônticos.

No entanto, há a possibilidade neste protocolo da hialuronidase facilitar a difusão do anestésico local não somente para o feixe nervoso, mas também para a circulação sanguínea e induzir efeitos cardiovasculares, muito embora quando injetada antes do final do efeito anestésico, a quantidade de anestésico local 
próximo ao nervo provavelmente já esteja reduzida, diminuindo o risco de efeitos adversos. Antes de testar este protocolo em pacientes sistemicamente comprometidos, primeiramente, viu - se por bem experimentá-lo em pacientes saudáveis. 


\section{REVISÃO DA LITERATURA}

Dentre as opções de anestésicos locais de ação intermediária do tipo amida disponíveis, a mepivacaína, droga de escolha para o experimento, é um dos anestésicos com menores propriedades vasodilatadoras. É a melhor opção disponível de anestésico local sem vasoconstritor (a 3\%) quando se executa procedimentos de curta duração e também, quando há contra-indicação de vasoconstritores. Para procedimentos que necessitam, porém, de duração de ação intermediária (cerca de 60 minutos), há necessidade de associação com vasoconstritor, a fim de proporcionar um tempo de trabalho adequado, sem o retorno da sensibilidade dolorosa (PRADO et al., 2000).

\subsection{Vasoconstritores}

Agentes vasoconstritores são freqüentemente utilizadas como adjuvantes de anestésicos locais pelo seu reconhecido efeito de aumentar a qualidade e a duração do bloqueio anestésico, diminuir a ação vasodilatadora do anestésico local e retardar a sua absorção pela circulação sistêmica e reduzir o sangramento no sítio cirúrgico (JASTAK; YAGIELA, 1983; NAFTALIN; YAGIELA, 2002). Ainda que consideradas seguras nas doses recomendadas em pacientes sadios, são crescentes os debates acerca dos riscos em sub-populações específicas, com destaque especial aos pacientes hipertensos, coronariopatas e portadores de insuficiência cardíaca e 
arritmias, que apresentam pouca capacidade de suportar ou se recuperar de situações de estresse (MALAMED, 2001; WYNN, 2000). Ademais, pacientes com co-morbidades cardiovasculares não raramente utilizam diversos fármacos que podem apresentar interações potencialmente perigosas com o vasoconstritor associado ao AL (JOWETT; CABOT, 2000).

\subsection{1 classes dos vasoconstritores}

Os vasoconstritores associados às bases anestésicas utilizadas na odontologia pertencem a duas classes: as aminas simpatomiméticas (epinefrina, norepinefrina, levonordefrina, felinefrina) e o análogo da vasopressina (felipressina).

A felipressina, também chamado de octapressina, é um análogo sintético do hormônio antidiurético (vasopressina) e, não exercer agonismo em receptores adrenérgicos. Tem um potencial de induzir complicações sistêmicas bem menor que os simpatomiméticos, sem a interação medicamentosa com os antihipertensivos. Porém, devido ao seu fraco efeito hemostático e indisponibilidade em diversos países, entre eles os Estados Unidos, tornam o seu uso bastante restrito (JASTAK; YAGIELA, 1983). Além disso, reduz o fluxo coronariano demonstrado em experimentação animal, quando utilizado na dose acima de 0,06 UI (AGATA; ICHINOHE; KANEKO, 1999; MIYACHI; ICHINOHE; KANEKO, 2003), devendo ainda ser comprovado se oferece risco para determinadas cardiopatias (BORSATTI; TAKAOKA, 2007). 
As aminas simpatomiméticas compreendem a classe de vasoconstritores mais comumente associados aos $\mathrm{AL}$, mas por evocarem respostas hemodinâmicas mais intensas e interações medicamentosas mais perigosas, tornaram-se alvo freqüente de discussões acerca de sua segurança cardiovascular (MALAMED, 2001; NAFTALIN; YAGIELA, 2002).

Dentre as aminas simpatomiméticas, a epinefrina é possivelmente a mais utilizada, em odontologia. Apesar de sua ação estar no estímulo tanto de receptores $\alpha$ quanto de receptores $\beta$, possui mais afinidade e se liga por mais tempo aos receptores $\beta$.

A ativação principalmente dos receptores a por uma droga simpatomimética leva à contração do músculo liso dos vasos sanguíneos (vasoconstrição). Os receptores $\beta$ são divididos em $\beta 1$ e $\beta 2$, sendo o primeiro responsável pela estimulação cardíaca e o segundo, pela vasodilatação em outros leitos.

Em concentração plasmática fisiológica de epinefrina (taxa de infusão inferior a $0,1 \mu \mathrm{g} / \mathrm{Kg} / \mathrm{min}$ ), predomina a ativação de $\beta$-receptores, ainda sem atingir a interação com $\alpha$-receptor. A ativação dos receptores $\beta 1$ pela epinefrina provoca aumento no influxo de cálcio nas células cardíacas, tendo conseqüências tanto elétricas quanto mecânicas. Há aumento da força de contração (inotropismo positivo), da FC (cronotropismo positivo) e da propagação da excitação através dos tecidos de condução (dromotropismo positivo). Já a interação da epinefrina com os receptores $\beta 2$ produz vasodilatação da musculatura esquelética e diminuição da resistência vascular e em outros leitos vasculares, com queda da pressão diastólica. Logo, como praticamente a pressão arterial média não se altera, não ocorre bradicardia reflexa. 
À medida que a concentração se eleva de dose moderada $(0,1$ a $1 \mu \mathrm{g} / \mathrm{Kg} / \mathrm{min})$ a alta (> $1 \mu \mathrm{g} / \mathrm{Kg} / \mathrm{min})$, estimula igualmente receptores a e $\beta$, porém a resposta pressora de $\alpha$ inicialmente mascara a resposta de $\beta$ (efeito bifásico da epinefrina), aumentando a resistência vascular, a pressão sistólica e agora, aumenta a pressão diastólica. Como conseqüência, pode haver aumento da pressão média e, então, bradicardia reflexa. Com a queda da concentração de epinefrina, volta a predominar a ativação sobre os receptores $\beta$ (MALAMED, 2001; NAFTALIN; YAGIELA, 2002).

2.1.2 Contra-indicações e interações medicamentosas dos vasoconstritores simpatomiméticos

É considerada contra-indicação absoluta o uso de vasoconstritor para os pacientes cardiopatas: (1) com angina instável, (2) infarto do miocárdio recente (até 6 meses), (3) cirurgia recente de artéria coronária (6 meses), (4) arritmias refratárias, (5) hipertensão severa não tratada ou não-controlada, (6) insuficiência cardíaca congestiva não tratada ou não controlada (PERUSSE; GOULET; TURCOTTE, 1992).

O uso de vasoconstritores adrenérgicos é uma contra-indicação relativa quando além do risco de interação medicamentosa entre o vasoconstritor e a medicação para o paciente cardiopata, ocorrer o uso de dose acima da recomendada por sessão ou injeção intravascular acidental. As medicações envolvidas nessa contra-indicação relativa são: $\beta$-bloqueadores não-seletivos, 
quinazolinas, bloqueador neuronal noradrenérgico de ação periférica, digitálicos e drogas diuréticas tiazídicas e de alta eficácia (BORSATTI; TAKAOKA, 2007).

a.) $\beta$-bloqueadores não-seletivos: Por bloquearem indistintamente tanto receptores $\beta 1$ quanto $\beta 2$, deixam livre de oposição os receptores $\alpha$. Os pacientes que fazem uso dessa classe de medicamentos ao receber a epinefrina associada ao anestésico local, podem ter quadro de hipertensão aguda e bradicardia reflexa, causadas pela estimulação dos a-receptores, cuja ação vasoconstritora foi preservada (CHAN; KARMAKAR; CHUI, 2002; JASTAK; YAGIELA, 1983).

b.) Quinazolinas: A prazosina, a doxazosina e a terazosina são agentes bloqueadores dos receptores $\alpha-1$ adrenérgicos pós-sinápticos, utilizados para tratamento da hipertensão. Ao bloquearem seletivamente esses receptores diminuem a resistência vascular, levando à queda da pressão arterial. Deixam, portanto, sem oposição os receptores $\beta 1$ e $\beta 2$, podendo ocorrer hipotensão arterial profunda e taquicardia (NAGUIB et al., 1998; WYNN, 2000).

c.) Bloqueador neuronal noradrenérgico de ação periférica: A guanetidina/guanadrel causa depleção da noradrenalina nas terminações nervosas pré-sinápticas, produzindo hipersensibilidade às ações das catecolaminas administradas exogenamente. Desse modo, o uso de vasoconstritores simpatomiméticos em soluções anestésicas locais pode resultar em graves distúrbios da pressão arterial e ritmo cardíaco (BORSATTI; TAKAOKA, 2007). 
d.) Digitálicos: Poderá haver interação com vasoconstritores adrenérgicos, principalmente a epinefrina, que é $\beta$-agonista, pelo aumento na atividade marcapasso ectópica (de ambas), levando a arritmias induzidas por digital (WYNN, 2000).

Nesses casos, a epinefrina e outros vasoconstritores adrenérgicos são contraindicados, podendo utilizar solução anestésica que contenha vasoconstritor nãoadrenérgico felipressina ou anestésico local sem vasoconstritor, se o procedimento clínico for de curta duração.

Se o procedimento for mais demorado é freqüente a necessidade da complementação anestésica. Esta pode ser ainda maior em determinadas técnicas que apresentam alto índice de falha no bloqueio nervoso, por exemplo, o bloqueio do nervo alveolar inferior, técnica mais frequentemente usada para anestesia local da mandíbula, apresenta taxas de falha de 8 a 67\% (HAWKINS; MOORE, 2002; MALAMED, 2001; RIDENOUR et al., 2001).

$\mathrm{Na}$ busca de solução para estes pacientes, pesquisas têm sido realizadas utilizando outros adjuvantes dos anestésicos locais, com a intenção de melhorar o índice de sucesso da anestesia e prolongar a duração da ação.

Entre os outros adjuvantes do anestésico local, tem-se a hialuronidase, que é um agente difusor utilizado principalmente em oftalmologia, há mais de 40 anos, e que pode ser injetada junto ao AL para melhorar a eficácia (CRAWFORD; KERR, 1994; NATHAN ET AL., 1996; SARVELA; NIKKI, 1992). 


\subsection{Hialuronidase}

O espaço extracelular, presente em todos os tecidos animais e vegetais, é preenchido por um complexo de componentes denominado matriz extracelular. Essa matriz é composta por inúmeras proteínas e polissacarídeos em proporções variáveis que se organizam formando uma rede. Sua quantidade varia conforme o tipo de tecido sendo abundante principalmente, nos tecidos conjuntivos.

O ácido hialurônico (ou hialuronato) é um polímero glicosaminoglicano não sulfatado encontrado na matriz extracelular. É formado pelo ácido glicurônico e Nacetilglicosamina alternadamente, os quais são ligados pela ponte $\beta-1,3$ ou $\beta-1,4$ (HYNES; WALTON, 2000) - Figura 2.1.

A hialuronidase foi identificada pela primeira vez por Duran (1929) ao perceber que a difusão de certas vacinas, tinturas e toxinas pelos tecidos quando injetadas subcutaneamente eram facilitadas por esta enzima. Dessa forma, passou a ser conhecida como "um fator de difusão" de substâncias através dos tecidos. Posteriormente constatou-se que esse fator de difusão se devia à quebra do ácido hialurônico - substância de interligação celular (FARR et al., 1997; HYNES; WALTON, 2000; SALMEN, 2003; WATSON, 1993).

Basicamente, a enzima hialuronidase, mais corretamente chamada de hialuronoglicosaminidase, liquefaz a barreira intersticial presente entre as células por clivar a ligação glicosídica $\beta-1,3$ ou $\beta-1,4$ entre o ácido glicorônico e Nacetilglicosamina, criando inúmeros oligossacarídeos, dependendo da origem da enzima. Essa hidrólise é uma reação reversível (FARR et al., 1997; HYNES; 
WALTON, 2000; WATSON, 1993), pois a estrutura do tecido é restabelecida num período de 2 a 4 dias, citado por Farr et al. (1997) em seu texto de revisão.

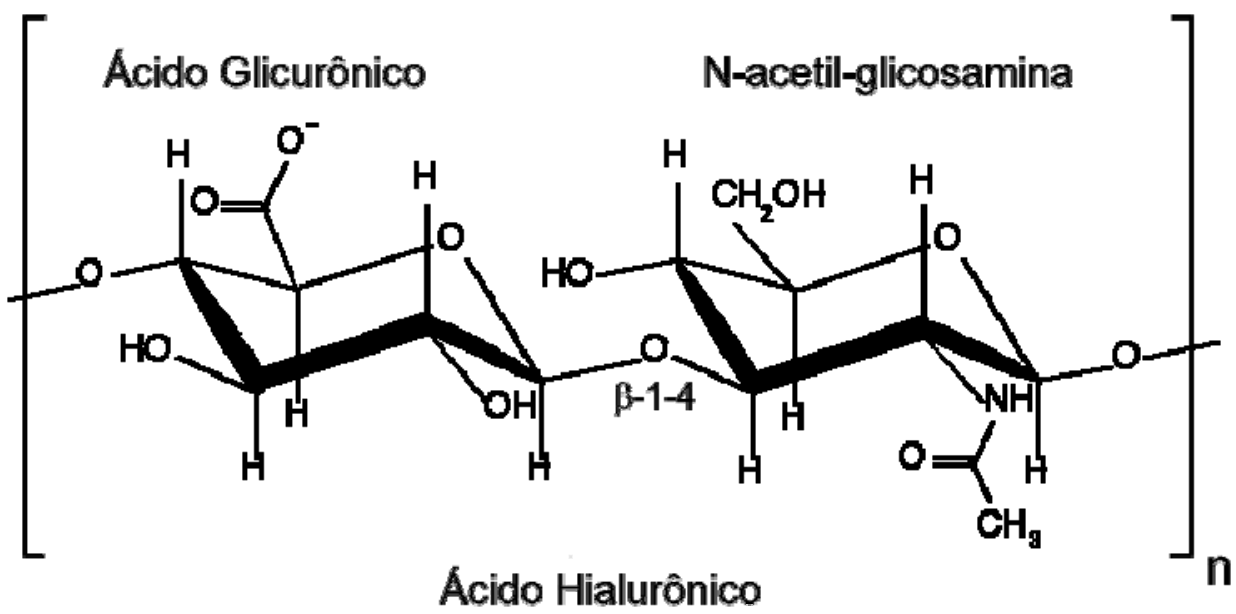

Figura 2.1 - Estrutura do ácido hialurônico. O retângulo mostra a subunidade (dissacarídeo) que se repete formando uma longa cadeia polissacarídea (Modificado de: Hynes e Walton, 2000)

Detectam-se isoformas da hialuronidase em diversos órgãos e tecidos, como por exemplo: testículos, olhos, pele, fígado, rins, baço, musculatura esquelética, útero, placenta, ovários, secreção nasal, líquido lacrimal e na parte posterior da hipófise (FARR et al., 1997; WATSON, 1993). A hialuronidase também está presente nos espermatozóides exercendo um importante papel na fertilização de muitos mamíferos, inclusive humanos. É encontrada, ainda, em outros animais como lagartos, peixes, aranhas, escorpiões, cobras, no veneno de abelhas e também em algumas bactérias e fungos (FARR et al., 1997; SALMEN, 2003).

Existem diferentes grupos de hialuronidase e quando isolados diferem quanto ao peso molecular e pH (SALMEN, 2003). A hialuronidase que utilizamos é do tipo testicular: Hialuronato-4-glicanohidrolase encontrada em mamíferos. Degrada o 
ácido hialurônico pela quebra da ligação 1,4- $\beta$-glicosídica sendo os tetrassacarídeos o principal produto (CRAWFORD; KERR, 1994) - figura 2.2. Sob a ação da hialuronidase a alta viscosidade do ácido hialurônico fica temporariamente diminuída, o que aumenta a difusão das substâncias injetadas pelos planos teciduais (FARR et al.,1997; SALMEN, 2003; STERN, 2001; WATSON, 1993).

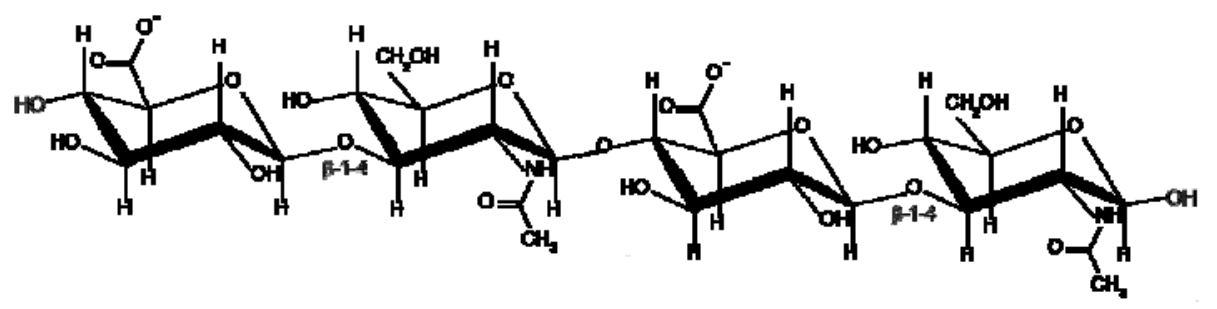

Figura 2.2 - Tetrassacarideo formado pela hialuronidase de testículo bovino. (Modificado de Salmen, 2003)

\subsubsection{1 farmacocinética da hialuronidase}

A determinação das características farmacocinéticas da hialuronidase não é simples, especialmente quando administrada por via intravenosa, porque a hialuronidase do próprio organismo também se encontra no sangue circulante e, além disso, os seres humanos possuem diversos tipos de inibidores de hialuronidase.

Quanto a sua absorção, ao ser aplicada uma injeção desta enzima, é inativada parcialmente por inibidores locais e absorvida pelo sistema circulatório. A depuração também ocorre de forma muito rápida nesta via de administração. 
Foi constatado que a administração de $500 \mathrm{UI}$ de hialuronidase/Kg de peso corpóreo, a depuração ocorre de 2,4 a 4,1 minutos (FARR et al., 1997).

A distribuição da hialuronidase efetua-se principalmente no fígado, rins e trato gastrointestinal. A meia vida da atividade enzimática sérica foi determinada como sendo $3,1 \pm 0,6$ minutos. A eliminação da hialuronidase é realizada em três fases: na primeira, é constatada uma rápida queda de atividade sérica; na segunda fase ocorre a passagem da enzima do ambiente intravascular para o extravascular, com duração de uma a duas horas. Na terceira fase, a hialuronidase é inativada e eliminada e este processo dura de uma a três horas (FARR et al., 1997).

\subsection{2 utilização terapêutica da hialuronidase}

Até o momento, a hialuronidase vem sendo mais amplamente utilizada nas áreas médicas cirúrgicas (LEWIS-SMITH, 1986). Por sua capacidade de reduzir a viscosidade da matriz extracelular, torna os tecidos mais permeáveis a fluidos injetados e promove: aumento da velocidade de difusão e absorção nos tecidos circundantes, reabsorção do excesso de fluidos extracelulares, diminuição da destruição tecidual causada pela injeção de fluidos pela via intramuscular e subcutânea e aumento da efetividade da anestesia local (FARR et al., 1997; SALMEN, 2003). 
Existem também estudos sobre a utilização da hialuronidase (hialuronato-4glicanohidrolase) utilizada isoladamente para indução do trabalho de parto (SPALLICCI, 2002).

Seu uso associado aos anestésicos locais é mais consagrado na oftalmologia. Em cirurgias oftalmológicas, vários estudos vêm sendo realizados com o objetivo de melhorar a eficácia dos bloqueios anestésicos tanto retrobulbar (KALLIO; PALOHEIMO; MAUNUKSELA, 2000; SARVELA; NIKKI, 1992) como peribulbar (BARR et al., 1995; GAO; BUDD, 1996; HAMADA et al., 2005; KALLIO; PALOHEIMO; MAUNUKSELA, 2000; NICOLL et al., 1986; SOARES et al., 2002). Em todos os casos, a hialuronidase é utilizada para facilitar a difusão do anestésico local através do tecido conjuntivo periocular (CRAWFORD; KERR, 1994; DEMPSEY; BARRET; KIRBY, 1997; MANTOVANI; BRYANT; NICHOLSON, 2001; NATHAN et al., 1996; SOARES et al., 2002; WATSON, 1993). Outros efeitos da hialuronidase como adjuvante dos anestésicos locais em oftalmologia são: a redução da latência do bloqueio nervoso (NICOLL et al., 1986; SARVELA; NIKKI, 1992), a diminuição da pressão intra-ocular (SOARES et al., 2002) e ação protetora da hialuronidase contra a injúria muscular causada pelos anestésicos locais (especialmente a bupivacaína) (HAMADA et al., 2005).

A associação de hialuronidase e etidocaína foi avaliada no bloqueio peribulbar em 70 pacientes submetidos à cirurgia de catarata, obtendo-se menores índices de falha anestésica com a associação anestésico-hialuronidase, bem como a necessidade de infusão de menores volumes de $A L$, o que evitaria complicações sistêmicas se for considerado o grande volume de solução anestésica necessária para esses bloqueios (SARVELA; NIKKI, 1992). 
Já Crawford e Kerr (1994) avaliaram a eficácia anestésica da hialuronidase injetada concomitante à mistura de lidocaína e bupivacaína durante o bloqueio peribulbar em 60 pacientes submetidos a cirurgias intra-oculares. Não foram encontradas diferenças significantes entre os grupos em relação à latência de ação, necessidade de suplementação, falha anestésica e condições cirúrgicas.

A hialuronidase altera a farmacocinética do anestésico local (SOARES et al., 2002). Barr et al. (1995) estudaram as diferenças entre a concentração plasmática máxima $\left(\mathrm{C}_{\max }\right)$ de quatro grupos distintos após a anestesia peribulbar. No grupo 1 utilizou-se uma mistura anestésica de lidocaína $10 \mathrm{mg} / \mathrm{mL}$ e bupivacaína $3,75 \mathrm{mg} / \mathrm{mL}$ de bupivacaína. Nos demais grupos, utilizaram-se a mesma mistura de AL, mas variando os adjuvantes: Grupo 2 - adrenalina $5 \mu \mathrm{g} / \mathrm{mL}$; Grupo 3 - hialuronidase (75UTR) e Grupo 4 - hialuronidase e adrenalina. Os autores concluíram que a adrenalina reduziu a $C_{\max }$ em $57 \%(p=0,001)$ para a lidocaína e 61\% $(p=0,004)$ para a bupivacaína comparando-se com os grupos sem adrenalina e sem hialuronidase. Já a hialuronidase não teve efeito significante na redução do pico de concentração plasmática, 90\% ( $p=0,34)$ para a lidocaína e 100\% $(p=0,84)$ para a bupivacaína, comparados com os grupos nos quais não se adicionou a hialuronidase. Embora a hialuronidase não tenha reduzido o pico de concentração plasmática, os autores concluíram que a sua adição não induziu a uma maior absorção sanguínea que fosse clinicamente relevante.

Em estudo semelhante, Gao e Budd (1996) tiveram como objetivo determinar em 25 pacientes a absorção sanguínea e o tempo para se atingir a concentração máxima $\left(T_{\max }\right)$ de anestésicos locais após o bloqueio peribulbar de lidocaína $2 \%$ e bupivacaína $0,75 \%$ (na proporção $1: 1$ ) sem a adição do vasoconstritor, mas com a hialuronidase a 150 UI. Os $T_{\max }$ da lidocaína $\left(C_{\max }=0,722 \mu \mathrm{g} / \mathrm{mL}\right)$ e da bupivacaína 
$\left(C_{\max }=0,353 \mu \mathrm{g} / \mathrm{mL}\right)$ foram de 10 e 20 minutos, respectivamente. A concentração plasmática esteve abaixo dos níveis tóxicos em todas as coletas durante os tempos (1 minuto após a anestesia e subsequentemente aos 10, 20, 30, 60 e 90 minutos). mais alto score de toxicidade $(0,915)$ foi obtido somente após uma das complementações anestésicas ficando muito próximo do nível de toxicidade. O score de toxicidade foi calculado dividindo-se o pico de concentração plasmática obtida durante o estudo pela concentração plasmática tóxica de $5 \mu \mathrm{g} / \mathrm{mL}$ (para a lidocaína) e 1,6 $\mu \mathrm{g} / \mathrm{mL}$ (para a bupivacaína).

Em estudo realizado por Nathan et al. (1996), foi demonstrado que a hialuronidase altera a farmacocinética do anestésico local administrado no bloqueio peribulbar. Esses autores compararam a associação de hialuronidase (100UTR/2mL) ou de água destilada (controle) à mistura de lidocaína $2 \%$ e bupivacaína 0,5\%. O tempo de latência anestésica foi menor no grupo hialuronidase, comparado ao grupo controle. A absorção dos AL também foi acelerada com o uso da hialuronidase, uma vez que o $T_{\max }$ para a lidocaína foi de $17,1 \pm 2,6$ min no grupo hialuronidase e $32,7 \pm 6,0$ min, no grupo controle. Para a bupivacaína, o $T_{\max }$ foi de $16,8 \pm 3,9$ min no grupo hialuronidase e $26,5 \pm 4,4$ min no grupo controle. A concentração plasmática máxima $\left(C_{\max }\right)$ dos $A L$, todavia, não foi afetada de forma significativa com a adição de hialuronidase. Em relação à meia vida plasmática e ao volume de distribuição final, não houve diferença significativa entre os grupos com hialuronidase e controle, tanto para a lidocaína, quanto para a bupivacaína. Os autores concluíram que a hialuronidase pode aumentar a difusão do AL do seu local de administração para a corrente sanguínea, porém, esse aumento na velocidade de absorção não altera a concentração plasmática máxima desses anestésicos, que foram menores que aquelas reportadas nas doses tóxicas. 
Para comparar os efeitos de diferentes concentrações de hialuronidase na qualidade do bloqueio peribulbar, Dempsey, Barrett e Kirby (1997), analisaram três grupos nos quais se utilizou $5 \mathrm{~mL}$ de mistura (1:1) de bupivacaína $0,5 \%$ e lidocaína $2 \%$. No grupo controle foi utilizada somente a mistura anestésica, enquanto nos outros dois grupos, acrescentou-se a hialuronidase nas seguintes concentrações: grupo 2 hialuronidase 50 UTR e grupo 3, 300 UTR. A hialuronidase nas duas concentrações aumentou a qualidade do bloqueio peribulbar aos 5 minutos; quando a concentração de 300 UTR foi utilizada, diminuiu-se também a latência do bloqueio. Os autores afirmaram que por esses benefícios, pela fácil administração e baixos níveis de toxicidade ou efeitos adversos, defendem o uso da hialuronidase na concentração de 300 UTR.

Num estudo em que foram efetuadas 714 cirurgias oculares, Kallio, Paloheimo e Manuksela (2000) observaram que a adição de hialuronidase $(3,75$ ou 7,5 UTR/mL) a uma mistura de $1: 1$ de bupivacaína $0,75 \%$ e lidocaína $2 \%$ resultou em uma redução da latência tanto dos bloqueios retrobulbares como dos peribulbares assim como na diminuição da necessidade de bloqueios complementares quando comparadas com o grupo no qual não foi utilizada a hialuronidase. Observaram, ainda, que a variação de concentração da hialuronidase não influenciou os resultados.

Como exposto, muitos estudos têm utilizado a hialuronidase como adjuvante dos anestésicos locais na oftalmologia. Em outras áreas de atuação, a adição da hialuronidase aos anestésicos locais ainda é controversa. Em cirurgias de enxerto de pele, Ahamed e Ahamed (2004) constataram que a associação da hialuronidase ao $\mathrm{AL}$ nas áreas doadoras confere vantagens como menor sangramento, maior duração da anestesia local e menor necessidade de complementação anestésica do 
que quando são utilizadas injeções múltiplas da mistura anestésica sem hialuronidase ou quando utilizado o anestésico tópico composto pela associação de lidocaína e prilocaína $\left(E M L A{ }^{\circledR}\right)$.

2.2. uso de hialuronidase em odontologia

O uso da hialuronidase em soluções de anestésico local para uso odontológico surgiu em 1949 (KIRBY; ECKENHOFF; LOOBY, 1949; LOOBY; KIRBY, 1949), porém não há menção da hialuronidase na literatura odontológica recente, com exceção do artigo de Ridenour et al. (2001).

Um número considerável de cirurgiões dentistas nos Estados Unidos passou a acrescentar a hialuronidase às soluções anestésicas e relataram seus casos de início consideravelmente rápido de anestesia, bem como o aumento da taxa de sucesso, principalmente do nervo alveolar inferior, enfatizando que a hialuronidase na odontologia é um assunto de grande interesse e que são necessárias investigações clínicas para demonstrar a eficácia, segurança e dosagem apropriada desta combinação antes de se preconizar seu uso (MALAMED, 2001).

Recentemente, Ridenour et al. (2001) utilizou hialuronidase 150 UTR concomitantemente ao anestésico local (lidocaína 2\% com epinefrina 1:100.000) com a intenção de melhorar o índice de sucesso do bloqueio pterigomandibular, porém, não observaram vantagens na mistura. Não houve diferença significativa no nível de desconforto durante a injeção do $A L$ entre os grupos com e sem hialuronidase. A taxa de sucesso anestésico, avaliada pela resposta ao estímulo 
elétrico pulpar, também não foi diferente entre os dois grupos. Dor local moderada e grave e trismo no pós-operatório ocorreram com incidência muito maior no grupo hialuronidase. Os autores concluíram que a associação da hialuronidase ao anestésico local além de não aumentar o índice de sucesso da anestesia local, aumentou a ocorrência de efeitos indesejáveis, chegando a contra-indicar a mistura para a odontologia.

Das muitas descobertas disponíveis sobre as possibilidades de aplicação desta enzima, não existe nenhum motivo, do ponto de vista toxicológico que contraindique a administração da hialuronidase para seres humanos. Além disso, a hialuronidase não consegue ultrapassar a barreira hemato-encefálica em pessoas saudáveis (FARR et al., 1997). Não pode ser excluída, todavia, a possibilidade de caráter antigênico da enzima, isoladamente ou em combinação. São raros os casos de alergia reportados na literatura (NICOLL et al., 1986; QUHILL; BOWLING; PACKARD, 2004; WATSON, 1993). Segundo Watson (1993), a hialuronidase possui um aparente papel no aumento intenso na permeabilidade vista em reações anafiláticas, sendo importante ter precaução em indivíduos susceptíveis (QUHILL; BOWLING; PACKARD, 2004; WATSON, 1993).

Alguns estudos citados anteriormente mostraram resultados controversos em relação à eficácia da associação de hialuronidase aos anestésicos locais (NATHAN et al., 1996; KALLIO; PALOHEIMO, MAUNUKSELA, 2000; SARVELLA; NIKKI, 1992; SOARES et al., 2002; RIDENOUR et al., 2001).

O que se questionou posteriormente (BORSATTI et al., 2004; HORLIANA, 2006) é o fato de a hialuronidase ser injetada no mesmo momento do AL, ou seja, quando a concentração local do anestésico na proximidade do feixe nervoso e vasos sangüíneos é bastante elevada. Essa pode ser a causa dos efeitos indesejados dos 
$\mathrm{AL}$, e ainda, da incapacidade em prolongar a duração da anestesia por dispersar as moléculas de anestésico local.

Foi então levantada a hipótese (Borsatti et al., 2004) de que se a hialuronidase fosse injetada isoladamente antes do término do efeito anestésico facilitaria a difusão e remanejaria as moléculas restantes de AL para o feixe nervoso, diminuindo a necessidade de complementação anestésica.

Restava saber qual era a quantidade requerida para se obter o bloqueio de condução e se havia quantidade suficiente para prolongá-lo se a hialuronidase fosse injetada nesse momento. Essa informação foi obtida no estudo de Popitz- Berguez et al. (1995).

Popitz- Berguez et al. (1995) avaliaram a relação intraneural do anestésico local, ou seja, a quantidade necessária no interior da fibra nervosa capaz de proporcionar o efeito anestésico. Utilizaram lidocaína a $1 \%$ marcada com $\mathrm{C}^{14}$, para o bloqueio do nervo ciático de ratos. Após a administração do anestésico, em 3 minutos, a fração intraneural foi de $1,3 \pm 0,5 \%$; em 15 minutos, de $1,9 \pm 0,17 \%$ e aos 30 minutos houve um decréscimo para $1,1 \pm 0,12 \%$ do total da dose administrada. Com o retorno da sensação dolorosa no $37^{\circ}$ minuto, a fração intraneural de anestésico foi de $0,4 \pm 0,02 \%$ do total injetado. Os autores observaram que durante o bloqueio da condução do impulso doloroso, entre o $5^{\circ}$ e $35^{\circ}$ minutos após a administração do anestésico, a concentração intraneural média de lidocaína foi de $1,6 \pm 0,12 \%$ da dose total injetada.

Durante o bloqueio do nervo periférico somente uma pequena quantidade (média de 1,6 \%) de anestésico local injetado pode alcançar o nervo para exercer seu efeito, pois existem barreiras anatômicas que são muito efetivas contra a difusão de drogas e apenas uma fração substancial do anestésico injetado é removida pela 
circulação sanguínea e absorvida localmente pelos tecidos que envolvem o nervo (Popitz- Berguez et al. (1995)

Apoiados nessa informação, Borsatti et al. (2004) testaram se o uso de hialuronidase (800 UTR) injetada antes do término do bloqueio nervoso reduziria as barreiras anatômicas e possivelmente aumentaria o acesso de moléculas de $\mathrm{AL}$ ao seu local de ação intraneural. Realizaram um estudo cego em bloqueio de nervo ciático de rato. A hialuronidase prolongou significativamente $(p<0,01)$ a duração do efeito anestésico local quando injetada antes da regressão do efeito anestésico comparada ao grupo controle (solução fisiológica). Também foi demonstrado nesse estudo que a hialuronidase não apresenta efeito anestésico local.

O estudo de HORLIANA (2006) demonstrou que a hialuronidase injetada aos 40 minutos do início do bloqueio do nervo alveolar inferior, ou seja, antes do término da anestesia (que durava em média 60 minutos), prolongou significativamente $(p<0,01)$ a duração do efeito anestésico local.

Há, porém, a possibilidade da hialuronidase facilitar a difusão do $A L$ não somente para o nervo, mas também para a circulação, induzindo efeitos cardiovasculares, muito embora quando injetada antes do final do efeito anestésico, a quantidade de AL próximo ao nervo provavelmente já esteja reduzida.

Investigações clínicas ainda não exploraram se a hialuronidase injetada antes da regressão do efeito $A L$ induz alterações na dinâmica cardiovascular. 
3 PROPOSIÇÃO

Verificar se a hialuronidase provoca alterações na dinâmica cardiovascular quando injetada isoladamente, antes da regressão do bloqueio nervoso. 


\section{CASUÍSTICA - MATERIAL E MÉTODOS}

\subsection{Casuística - Material}

\subsubsection{Casuística}

A participação de pacientes voluntários neste estudo foi permitida após consentimento informado por escrito (Anexo B), respeitando o protocolo aprovado no parecer do Comitê de Ética em Pesquisa n 54/03 (Anexo A). Desse modo, participaram do estudo vinte pacientes, de ambos os gêneros, com idades entre 18 e 35 anos, normorreativos, estado físico ASA I (Amercian Society of Anesthesiologistis Physical Status Classification System, citado por MALAMED, 2001).

Os pacientes foram selecionados no Setor de Urgência Odontológica e na Clínica Odontológica Ambulatorial, ambas da Faculdade de Odontologia da Universidade de São Paulo, e foram aceitos os que deram a sua anuência e preenchiam os critérios de inclusão da pesquisa.

\subsubsection{Critérios de Inclusão}

Foram incluídos na pesquisa: 
1 - Pacientes que apresentavam os dois terceiros molares inferiores semiinclusos com disposição anatômica simétrica bilateral entre eles, segundo a classificação I ou Il e posição A ou B de Pell e Gregory (1933) - Apêndice A e com indicação para exodontia (por má posição dental, planejamento ortodôntico, etc.). Deveriam possuir pelo menos um pré-molar hígido de cada lado ou com restauração classe I rasa, avaliado clínica e radiograficamente, com vitalidade, sem alterações periodontais e previamente assintomático, para que nesse dente fosse realizado o teste pulpar elétrico para verificação da duração da ação anestésica.

2 - História médica negativa, pressão arterial sistólica menor que $140 \mathrm{mmHg}$, diastólica menor que $90 \mathrm{mmHg}$ e freqüência cardíaca com valores entre 60 e $110 \mathrm{bpm}$.

\subsubsection{Critérios de Exclusão}

Foram excluídos:

1 - Voluntários que fizessem uso de qualquer medicação no período de quinze dias antes da primeira consulta clínica ou entre as consultas, exceto anticoncepcionais (por não haver interação medicamentosa com os fármacos utilizados na pesquisa) e a medicação pós-operatória prescrita;

2 - Fumantes, gestantes ou alérgicos a qualquer fármaco utilizado na pesquisa; 
3 - Distúrbios clínicos associados ao colágeno: escorbuto, Síndrome de Ehlers Danlos, osteogênese imperfeita, artrite reumatóide. Também foram excluídos pacientes com neoplasias ou infecções conhecidas;

4 - Pacientes que apresentassem pericoronarite ou abscesso periodontal nos terceiros molares inferiores;

5 - Pacientes que, durante o procedimento cirúrgico, necessitassem de volume maior que o padronizado no experimento; vale ressaltar que esses receberam a quantidade necessária de $A L$ até o final da cirurgia;

6 - Pacientes com índice de massa corpórea maior que 20 e menor que 25.

\subsubsection{Material de Consumo}

1. Exame radiográfico: filme periapical, tipo Ektaspeed ${ }^{\circledR}$;

2. Procedimento cirúrgico: gaze estéril, fio de sutura de seda 3.0 , com ponta montada, sugadores cirúrgicos e lâmina de bisturi $n^{0} 15$;

3. Anti-sepsia extra e intra-oral: clorexidina $2 \%$ e solução de gluconato de clorexidina $0,12 \%$, respectivamente;

4. Barreiras de biossegurança: óculos de proteção, gorro, máscara, luva cirúrgica, avental e campo cirúrgico estéreis.

5. Gel condutor para eletrocardiografia e ultra-sonografia (Med System ${ }^{\circledR}$ ) para realizar o teste pulpar;

6. Anestesia local: agulhas longas descartáveis calibre $27 G$ (Gengibras ${ }^{\circledR}$ ), solução anestésicas 
7. Mepivacaína 2\% com adrenalina 1:100.000, em tubetes de $1,8 \mathrm{ml}$ para seringa carpule (DFL Ind. Com. - lote 0411C18 - validade novembro/2006);

Assim, cada 1,0mL de solução contém:

\begin{tabular}{c|c}
\hline Composição & Quantidade \\
\hline Cloridrato de Mepivacaína & $20 \mathrm{mg}$ \\
\hline Epinefrina base & $10 \mu \mathrm{g}$ \\
\hline Cloreto de Sódio & $6,5 \mathrm{mg}$ \\
\hline Metabissulfito de Potássio & $1,2 \mathrm{mg}$ \\
\hline Edetato Dissódico & $0,25 \mathrm{mg}$ \\
\hline Veículo & q.s.p. $1,0 \mathrm{~mL}$ \\
\hline
\end{tabular}

Quadro 4.1 - Composição de 1,0mL da solução anestésica

A solução de hialuronidase foi manipulada em frascos de 1,0mL para seringa carpule pela Apsen Farmacêutica S/A (Quadro 4.1). Cada 1,0mL de solução contém:

\begin{tabular}{c|c}
\hline Composição & Quantidade \\
\hline Hialuronidase & 75 UTR \\
\hline Água destilada para injetáveis & q.s.p. $1,0 \mathrm{~mL}$ \\
\hline
\end{tabular}

Quadro 4.2 - Composição de 1,0mL de solução de hialuronidase

A água destilada para injetáveis (grupo controle - placebo) foi preparada e envasada em frascos de $1,0 \mathrm{~mL}$ para seringa carpule pela Apsen Farmacêutica S/A (figura 4.1). Assim, cada 1,0mL de solução continha: 


\begin{tabular}{c|c}
\hline Composição & Quantidade \\
\hline Água destilada para injetáveis & $1,0 \mathrm{~mL}$ \\
\hline
\end{tabular}

Quadro 4.3 - Composição de 1,0mL de placebo

Como se tratou de estudo duplo-cego, os frascos foram envasados e codificados pelo fabricante com os códigos: 0406013 e 0406014 sendo que a informação que revelava sobre qual frasco continha cada solução se encontrou em poder do Comitê de Ética em Pesquisa da FOUSP, até o final da análise estatística, portanto nem o paciente, nem os pesquisadores tiveram conhecimento de qual droga estava sendo utilizada em cada sessão (Figura 4.1). A administração destas soluções contidas nos frascos foi realizada após a aspiração total do volume líquido da hialuronidase ou da água destilada através da seringa de aspiração (Figura 4.2) utilizando-se do mesmo frasco tubete do AL administrado no paciente.

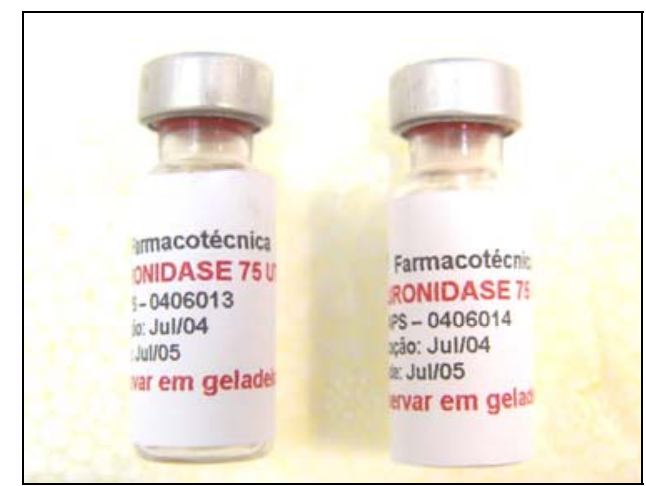

Figura 4.1 - Frascos codificados com solução de hialuronidase ou de água destilada preparadas e envasadas em frascos de $1,0 \mathrm{ml}$ pela Apsen Farmacêutica S/A

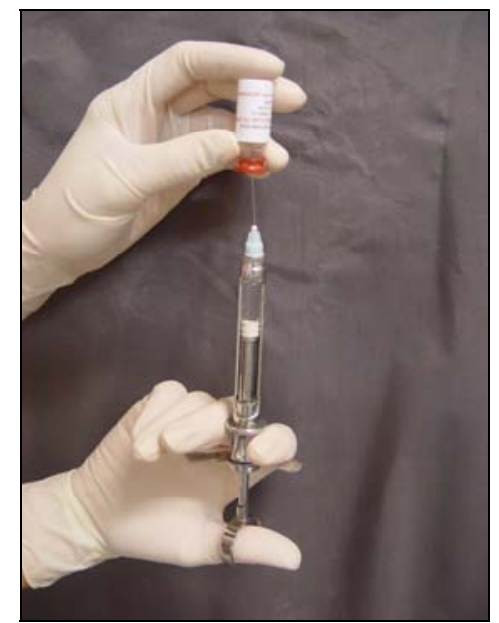

Figura 4.2 - Solução de hialuronidase e solução de água destilada sendo aspiradas para o tubete de anestésico local vazio 


\subsubsection{Material Permanente}

\subsubsection{1 instrumental}

1 - Exame clínico: espelho e pinça clínica, explorador duplo;

2 - Anestesia local: Seringa carpule de aspiração (Health Co ${ }^{\circledR}$, USA)

3 - Procedimento cirúrgico: pinça cirúrgica, cabo para bisturi, sindesmótomo, caneta de alta rotação com irrigação, brocas cirúrgicas, elevadores, fórceps, cinzéis, martelo cirúrgico, pinça mosquito, osteótomo, lima óssea, cureta cirúrgica, seringa descartável de $20 \mathrm{~mL}$, porta-agulha, afastadores, tesoura reta de ponta romba (material utilizado na Disciplina de Cirurgia da Faculdade de Odontologia da Universidade de São Paulo);

\subsubsection{2 aparelhos}

1. Avaliação da Pressão Arterial durante a seleção dos pacientes: esfigmomanômetro (Tycos $750^{\circledR}$ ) e estetoscópio (Littmann Classic II ${ }^{\circledR}$ );

2. Avaliação da anestesia pulpar: Aparelho Pulptest Vitality Scanner Model $2005^{\mathrm{TM}}$ (Analytic, USA). 

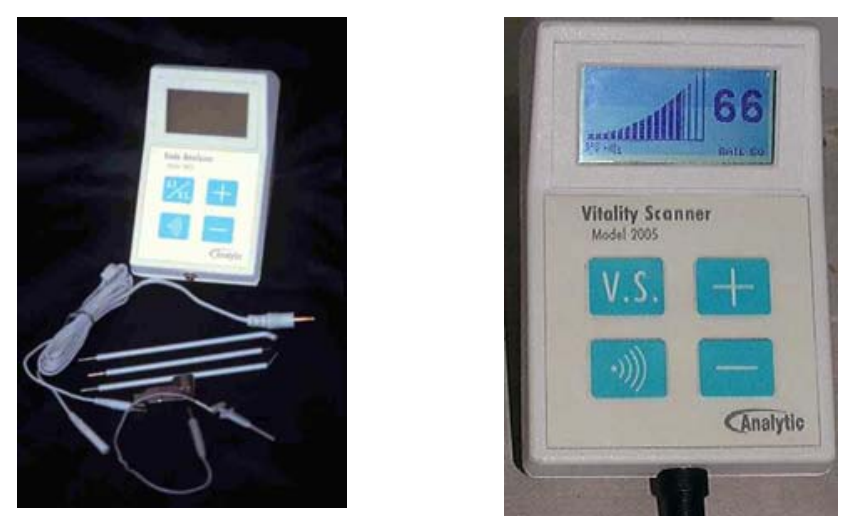

Figura 4.3 Pulp Test Vitality Scanner Model 2005 (Analytic USA)

Monitoração e registro dos parâmetros cardiovasculares: monitor automático de pressão sanguínea não-invasivo - modelo SCHOLLAR II, Criticare System ${ }^{\circledR}$ (Inc, USA), com impressora para registro contínuo das pressões arteriais.

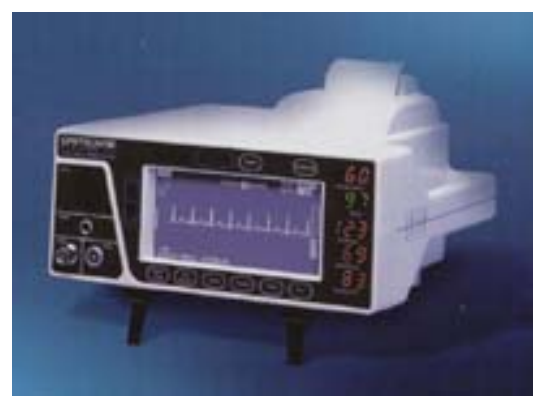

Figura 4.4 - Aparelho SCHOLLAR II, Criticare System ${ }^{\circledR}$ (Inc, USA) 


\subsection{Métodos}

\subsubsection{Avaliação clínica para seleção dos pacientes}

Logo após os pacientes terem preenchido o termo de consentimento livre e esclarecido para participar da pesquisa, foi realizada a anamnese e exame físico. Para anamnese, foi utilizada ficha clínica completa preparada para a pesquisa (Anexo C) e foi considerada história médica negativa quando nenhuma alteração de saúde geral do paciente era observada e quando não se fazia uso de qualquer medicação. Em seguida, era feita a avaliação clínica odontológica, com exame radiográfico e de alguns parâmetros cardiovasculares para verificar se preenchiam os requisitos da pesquisa.

Para o exame radiológico, foi feita a técnica radiográfica periapical na região dos terceiros molares e dos pré-molares inferiores bilateralmente e quando necessário, foi complementada com a radiografia panorâmica.

Os parâmetros cardiovasculares avaliados na seleção foram: a pressão arterial sistólica e diastólica através dos métodos auscultatório com esfigmomanômetro colocado no braço esquerdo do paciente sentado e estetoscópio adaptado sobre a artéria braquial deste mesmo braço. A freqüência cardíaca foi obtida através da palpação no pulso radial durante um minuto. 
4.2.2 Metodologia do atendimento clínico

Os pacientes foram agendados para realização de exodontia no consultório odontológico no Centro de Pesquisa Clínica do Departamento de Estomatologia da FOUSP. Cada paciente foi atendido em duas sessões, com um intervalo mínimo de quinze dias entre elas. Os pacientes sempre foram anestesiados e operados pela mesma cirurgiã-dentista nas duas consultas. As pacientes do sexo feminino foram agendadas fora ao período menstrual

\subsubsection{Metodologia para a aplicação da anestesia local}

Neste estudo, a solução teste de hialuronidase 75 UTR ou água destilada (utilizada de modo duplo-cego) foi injetada antes do término do efeito $A L$ da mepivacaína com adrenalina. Na literatura, como a média de duração de ação dessa associação $A L$ varia de 50 a 60 minutos, as soluções testadas foram injetadas 10 minutos antes desse momento, ou seja, aos 40 minutos.

Em cada sessão foi realizado um procedimento cirúrgico, sendo administrado o anestésico local com vasoconstritor e após 40 minutos a solução de hialuronidase ou placebo, pela mesma via e técnica utilizada para o bloqueio dos nervos alveolar inferior e lingual.

Cada paciente recebeu os dois grupos de soluções em ordem aleatória e sendo o estudo duplo-cego, tanto paciente quanto pesquisador não tiveram conhecimento 
de qual droga estava sendo utilizada em cada sessão. Os códigos das soluções de hialuronidase e água destilada foram revelados no final do experimento.

Foi utilizada técnica anestésica indireta de bloqueio de condução dos nervos alveolar inferior e lingual, e para anestesia do nervo bucal, utilizou-se a técnica infiltrativa (MALAMED, 2001). O volume de anestésico local foi o mesmo para todas as cirurgias, totalizando $2,8 \mathrm{~mL}: 1,8 \mathrm{~mL}$ na técnica pterigomandibular e $0,9 \mathrm{~mL}$ pela técnica infiltrativa do nervo bucal. As soluções testadas (hialuronidase e água destilada) foram injetadas apenas para o bloqueio do nervo alveolar inferior e lingual, e não na técnica infiltrativa do nervo bucal. A velocidade de injeção foi de aproximadamente $1,0 \mathrm{~mL}$ por minuto. Foram realizadas aspirações prévias no início da injeção e a cada mudança da posição da agulha, tanto para a administração dos anestésicos locais, como para as soluções testadas.

Nos casos em que houve necessidade de complementação anestésica, o paciente foi descartado do estudo.

4.2.4 Metodologia utilizada para o registro do início da anestesia

Antes de iniciar a anestesia local, foi verificado o valor basal de limiar de dor através do teste elétrico no pré-molar inferior que variou de 30 a 50 (pontuação no visor do aparelho). Este teste foi realizado a cada dois minutos até a perda da sensibilidade (o visor do aparellho mostra valores crescentes de estimulação elétrica até o score máximo de 80 ), que indica objetivamente o início do bloqueio da condução nervosa, ou seja, início da ação anestésica local. O teste foi realizado no 
pré-molar inferior colateral ao terceiro molar a ser avulsionado com a finalidade de avaliar a profundidade anestésica.

4.2.5 Metodologia para a realização dos procedimentos cirúrgicos

A técnica cirúrgica para exodontia dos terceiros molares inferiores foi a preconizada pela Disciplina de Cirurgia e Traumatologia Buco-Maxilo-Facial da FOUSP, sendo composta basicamente pelas etapas: anti-sepsia extra e intraoral, anestesia local, incisão do tecido mole, sindesmotomia, odontossecção, luxação, avulsão, curetagem alveolar, sutura e tamponamento.

4.2.6 Estudo das variáveis

4.2.6.1 método de avaliação cardiovascular

Durante os experimentos foram aferidos e registrados os valores da pressão arterial sistólica (PS), pressão arterial diastólica (PD), pressão arterial média (PM) e freqüência cardíaca (FC), através do monitor CRITICARE $^{\circledR}$ modelo Scholar II (Criticare System, USA). 
No decorrer da cirurgia, o voluntário permaneceu sentado na cadeira odontológica semi-inclinada ( $45^{\circ}$ ao chão) e o braço esquerdo posicionado paralelo ao tronco. O manguito foi adaptado ao braço esquerdo, no nível do coração, e o paciente foi instruído para limitação de movimento. $O$ dispositivo com fotopletismógrafo ("cuff finger" ou sensor digital) foi adaptado à falange distal do dedo indicador da mão direita. Após o preparo do voluntário iniciou-se a calibração automática de rotina dos registros dos parâmetros cardiovasculares por cinco minutos, para estabilização e determinação de uma escala de valores de base para a pressão arterial e freqüência cardíaca para cada voluntário. Após este período o paciente permaneceu em repouso por mais quinze minutos. Deste total de vinte minutos foram selecionados os últimos dez que foram considerados o controle da experiência, ou período basal, ou seja, todas as outras etapas foram comparadas a esta, com o paciente em repouso e sem nenhuma atividade clínica sendo executada.

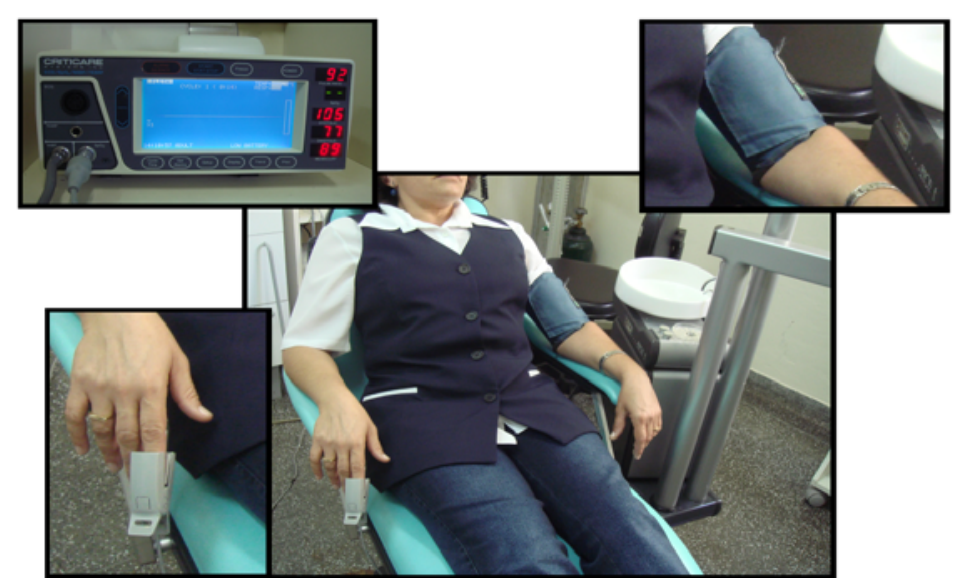

Figura 4.5 - Monitoração dos parâmetros cardiovasculares dos pacientes 
4.2.7 Dinâmica da experiência

4.2.7.1 fase pré-anestésica

1. Anti-sepsia (bochecho com Periogard ${ }^{\circledR}$ );

2. Início do registro dos parâmetros cardiovasculares com o paciente sentado na cadeira odontológica;

3. Realização do teste elétrico pulpar, para anotação do valor numérico obtido pelo aparelho, correspondente ao valor basal do pré-molar colateral à cirurgia.

\subsubsection{2 fase anestésica}

1. Administração da anestesia local;

2. Realização do teste elétrico pulpar até a ausência de sensibilidade pulpar no pré-molar testado, a cada minuto;

3. Cronometragem dos 40 minutos após o início da AL pulpar necessários para a administração da solução teste (hialuronidase ou água destilada). 
4.2.7.3 fase cirúrgica

1. Incisão do tecido mole;

2. Sindesmotomia;

3. Odontossecção (com broca), quando necessário;

4. Luxação;

5. Avulsão;

6. Curetagem;

7. Sutura;

8. Administração da hialuronidase ou água destilada para injetáveis (aos 40 minutos após o início do efeito anestésico). Este momento da administração poderia ocorrer antes ou depois da sutura, desde que fosse $040^{\circ}$ minuto da anestesia local.

\subsubsection{4 fase pós-operatória}

Final da monitoração dos parâmetros cardiovasculares até 10 minutos após a volta da sensibilidade pulpar e gengival. Embora o monitor automático forneça registros a cada 1 minuto, foram selecionados para análise 12 tempos: $5 a$ (5 minutos antes do $A L), A L$ (anestesia), 5d (5 minutos após $A L)$, incis (incisão), sind (sindesmotomia), lux (luxação), av (avulsão), curet (curetagem), sut (sutura), 
fim (5 minutos após sutura), h (hialuronidase/placebo) e 30d (30 minutos após a hialuronidase/placebo).

\subsubsection{Estudo estatístico}

Para a análise estatística dos valores médios das variáveis PS, PD, PM e FC foi realizada Análise de Variância (ANOVA) com 2 fatores de variação: hialuronidase (H) e tempo $(T)$, no nível de significância de $1 \%$. O teste auxiliar Tukey foi utilizado para a variável FC. 


\section{RESULTADOS}

\subsection{Dados demográficos}

As médias aritméticas e os desvios-padrões dos dados demográficos da população estudada (idade, gênero, peso, altura e índice de massa corpórea) estão dispostos na Tabela 5.1. As médias aritméticas e os desvios-padrões dos tempos de cirurgia estão dispostos na Tabela 5.2.

Tabela 5.1 - Média aritmética e desvio padrão dos dados demográficos

\begin{tabular}{c|c|c}
\hline $\begin{array}{c}\text { Dados } \\
\text { Demográficos }\end{array}$ & Média Aritmética & Desvio Padrão \\
\hline $\begin{array}{c}\text { Média de idade } \\
\text { (anos) }\end{array}$ & 23 & $\pm 3,9$ \\
\hline Gênero & $7(\mathrm{H})^{*} 13(\mathrm{M})^{* *}$ & --- \\
\hline Peso $(\mathrm{Kg})$ & 62 & $\pm 9,2$ \\
\hline Altura $(\mathrm{m})$ & 1,65 & $\pm 8,5$ \\
\hline $\mathrm{IMC}\left(\mathrm{Kg} / \mathrm{m}^{2}\right)$ & 22 & $\pm 2,2$ \\
\hline
\end{tabular}

IMC: Índice de massa corpórea

${ }^{*}$ homens ${ }^{* *}$ mulheres

Tabela 5.2 - Valores da média aritmética e desvio padrão para as durações dos atos cirúrgicos

\begin{tabular}{l|c|c}
\hline $\begin{array}{l}\text { Duração dos atos } \\
\text { cirúrgicos }\end{array}$ & Média Aritmética & Desvio Padrão \\
\hline Hialuronidase (minutos) & 60,9 & $\pm 15,4$ \\
\hline Placebo (minutos) & 66,4 & $\pm 16,2$ \\
\hline
\end{tabular}

Os detalhes da análise estatística descritiva para os dados demográficos e de duração do procedimento cirúrgico se encontra nos Apêndices B, C, D e E. 


\subsection{Pressão Sistólica, Diastólica, Média e Freqüência Cardíaca}

Para todas as variáveis (PS, $P D, P M$ e $F C$ ) os valores médios obtidos não diferiram ( $p>0.01$ ) entre os grupos com hialuronidase e placebo. Também não houve diferença significativa entre os valores médios na interação entre os fatores hialuronidase/placebo e tempo $(\mathrm{H} \times \mathrm{T})$.

Os gráficos que representam a comparação entre as variáveis cardiovasculares, o fator tempo e o uso de hialuronidase ou placebo estão listados a seguir.

A análise de variância ANOVA e o teste de Tukey - para a variável FC - estão detalhados nos apêndices F, G, H, I, J, K e L.

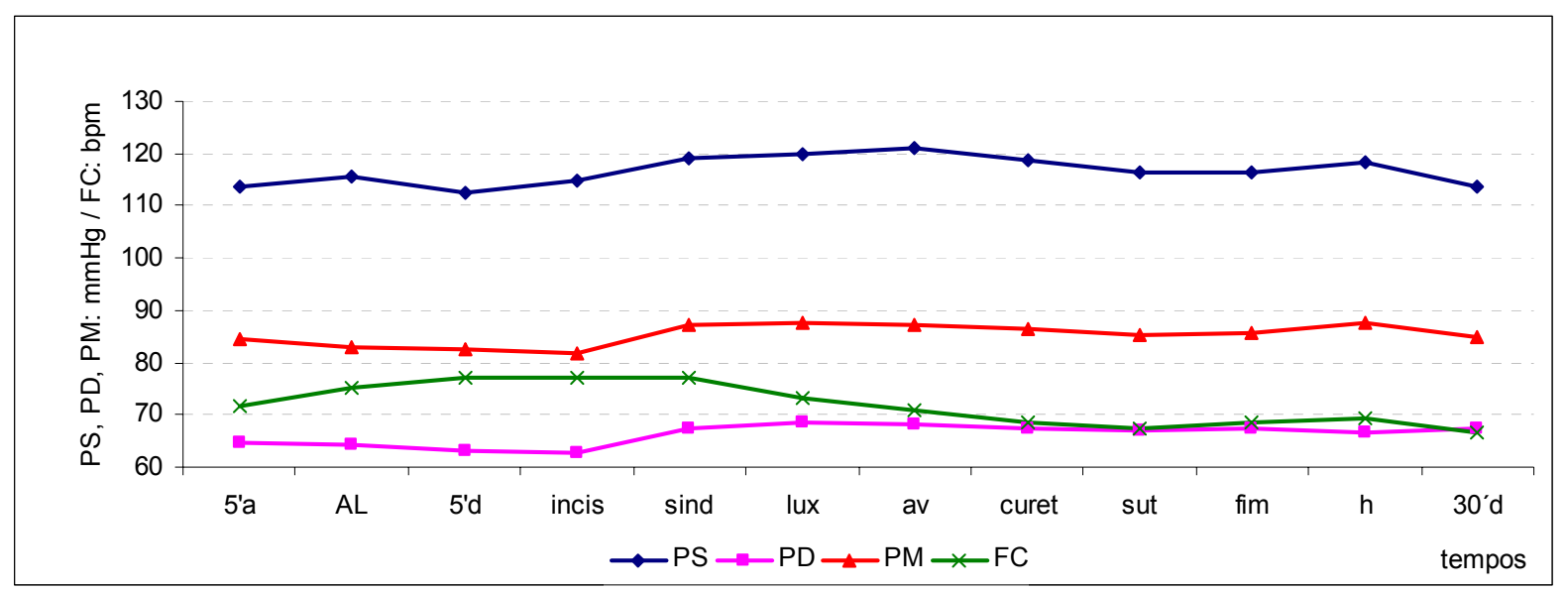

Gráfico 5.1 Valores médios das Variáveis Cardiovasculares obtidos da mepivacaína com epinefrina seguida de hialuronidase 


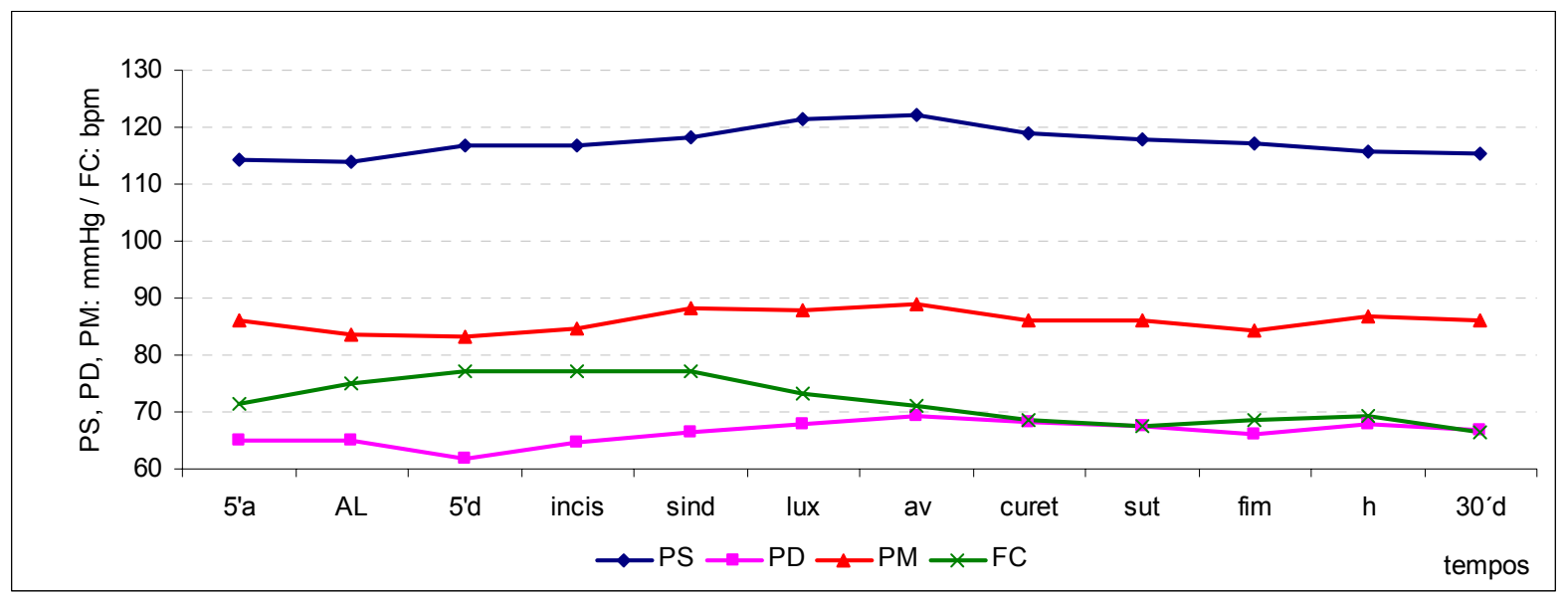

Gráfico 5.2 Valores médios das Variáveis Cardiovasculares obtidos da mepivacaína com epinefrina seguida de placebo

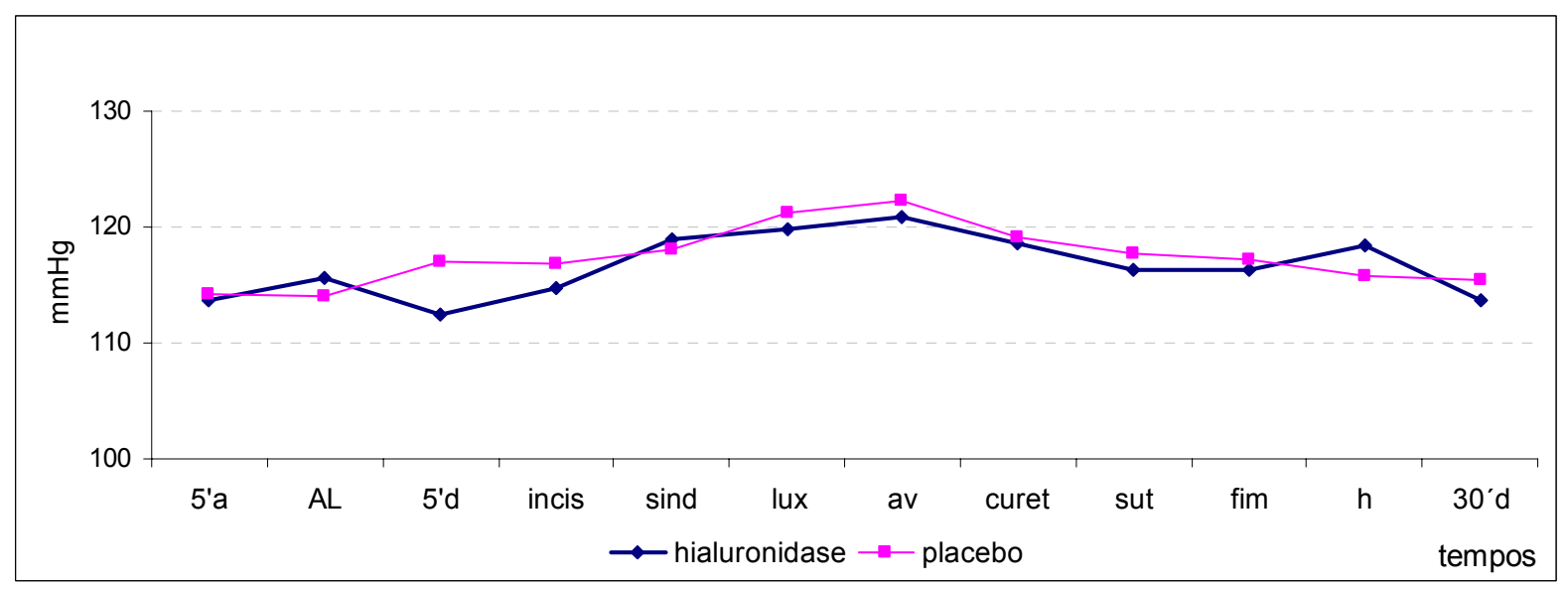

Gráfico 5.3 Valores médios da Pressão Arterial Sistólica

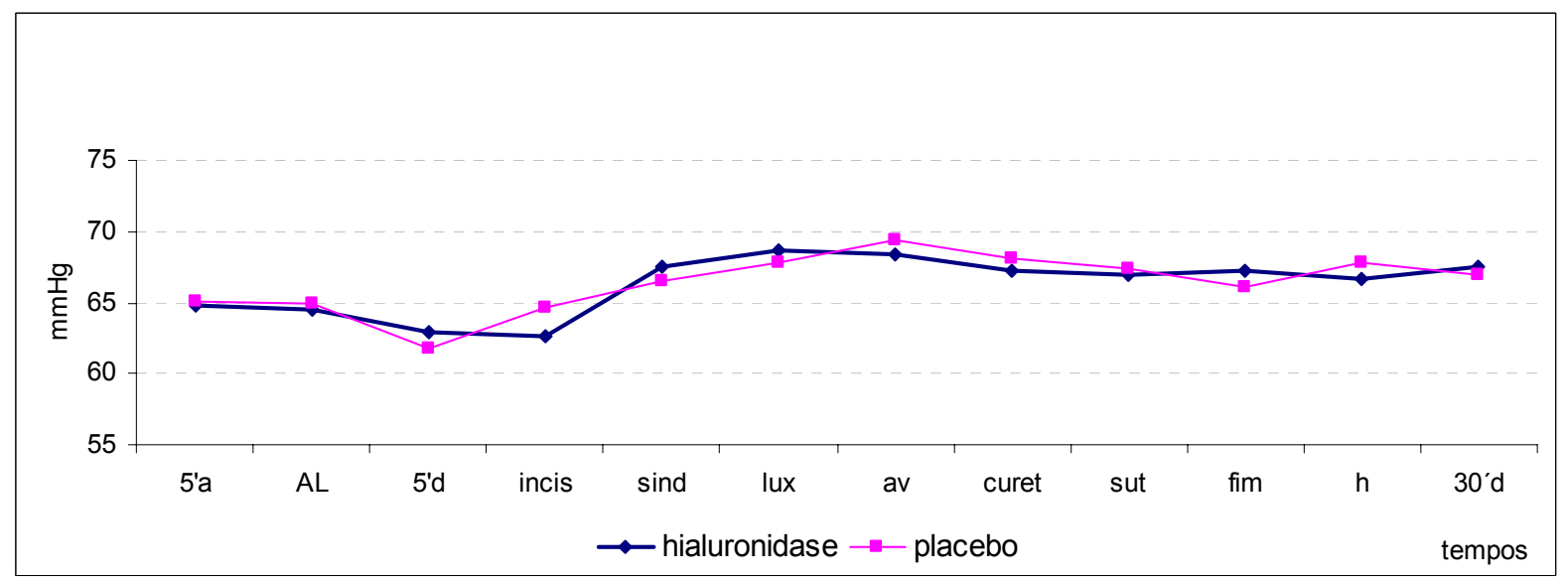

Gráfico 5.4 Valores médios da Pressão Arterial Diastólica 


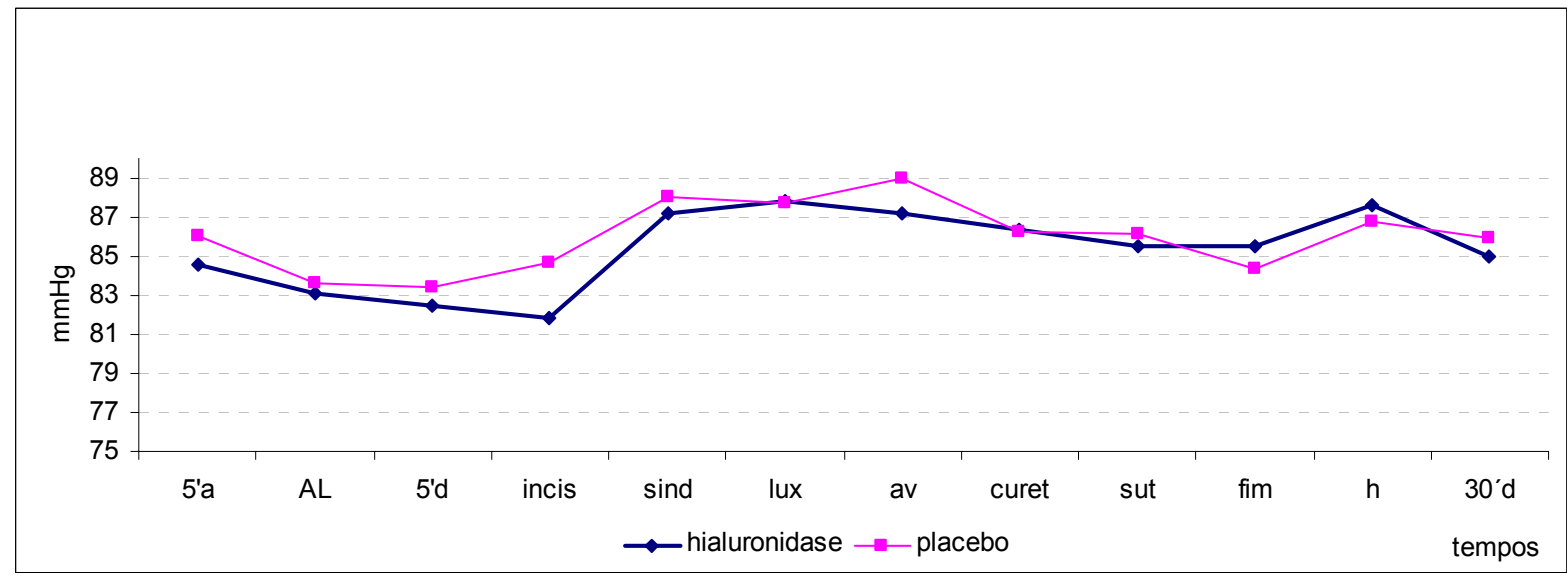

Gráfico 5.5 Valores médios da Pressão Arterial Média

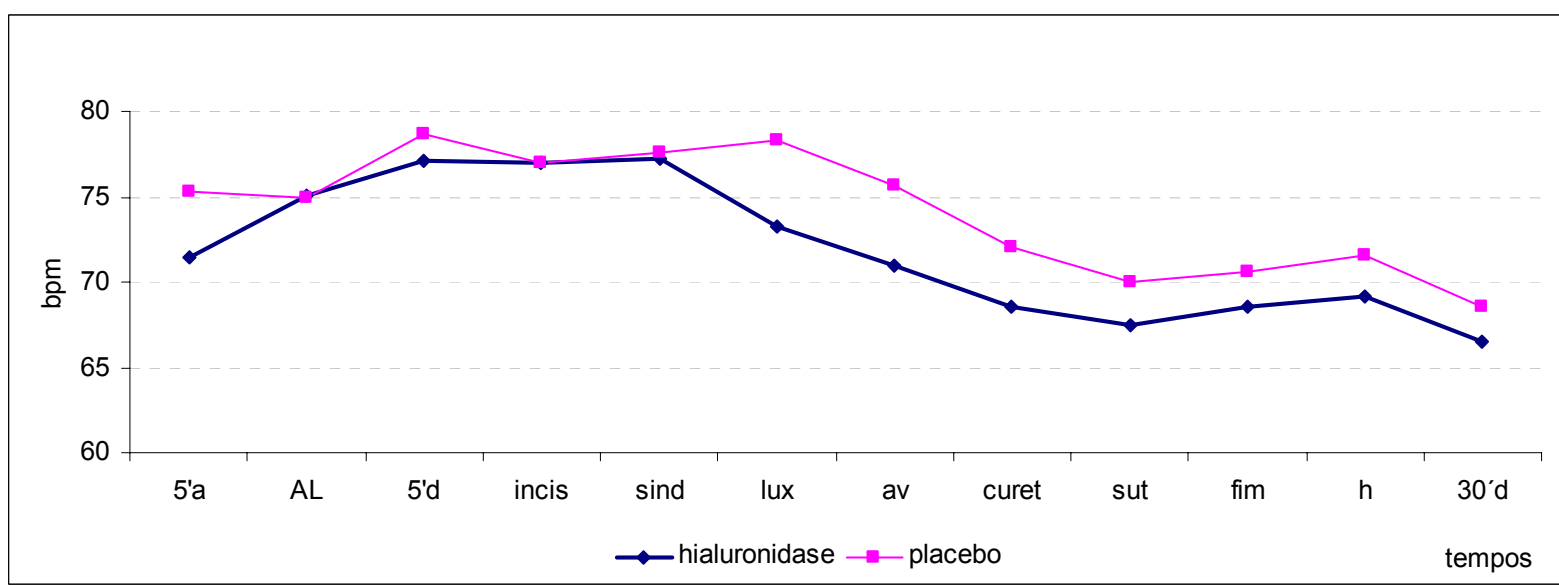

Gráfico 5.6 Valores médios da Frequência Cardíaca 


\section{DISCUSSÃO}

A disseminação do uso da associação anestésico local e hialuronidase, na oftalmologia, deve-se à melhora na qualidade da anestesia em infiltrações peribulbares e nos bloqueios retrobulbares. Em outras especialidades, seu uso é menos freqüente e na odontologia, ainda é praticamente desconhecido.

Muitos estudos clínicos afirmam que a hialuronidase somente é efetiva nos bloqueios peribulbares e retrobulbares (NATHAN et al., 1996; SARVELA; NIKKI, 1992) e que sua eficácia não foi comprovada em nenhum outro sítio (NICOLL et al., 1986). Sarvela e Nikki (1992) advogam que talvez não seja efetiva porque nos outros locais onde foi testada devem existir barreiras anatômicas mais espessas que os tecidos que envolvem o globo ocular. Assim, em outras áreas da medicina, a indicação e os benefícios obtidos com a associação ainda permanecem controversos, além de não haver consenso quanto à concentração e volume adequados para a hialuronidase a ser administrada (BRYDON, BASLER, KERR, 1995; DEMPSEY; BARRETT; KIRBY, 1997; KALLIO; PALOHEIMO; MAUNUKSELA, 2000).

Particularmente na odontologia, o estudo de Ridenour et al. (2001), empregando hialuronidase 150 UTR injetada junto ao AL para o bloqueio pterigomandibular, não alcançou o propósito de aumentar o índice de sucesso da anestesia local além de induzir efeitos adversos de dor e trismo no pós-operatório, levando os autores a contra-indicarem seu uso.

Ainda, o que havia em comum entre todos os estudos, tanto em medicina quanto em odontologia, era o momento em que a hialuronidase era injetada, ou seja, 
sempre concomitante ao anestésico local. Embora Ridenour et al. (2001) não tenham explicado em seu estudo porque ocorreram os efeitos adversos de dor e trismo, é possível que a hialuronidase injetada concomitante ao AL tenha facilitado a difusão deste do local de ação, e assim, reduzido a duração do bloqueio nervoso e levando à dor, além de difundir o $\mathrm{AL}$, que no momento inicial da anestesia estava em alta concentração, para tecidos adjacentes ao da cirurgia, causando trismo.

Essa possibilidade encontra apoio na citação de alguns autores que afirmam que a adição de hialuronidase reduz a duração de ação do anestésico local por aumentar a sua difusão para os tecidos, além de aumentar sua velocidade de absorção sanguínea (BRYDON, BASTER, KERR, 1995; MALAMED, 2001; NATHAN et al., 1996).

Foi demonstrado em nervo ciático de rato, com lidocaína marcada radioativamente que a fração intraneural de anestésico local capaz de bloquear a condução nervosa é muito pequena, apenas $1,6 \pm 0,12 \%$ da dose injetada e o restante fica nas proximidades da fibra nervosa e se difunde para tecidos adjacentes (POPITZ-BERGER et al., 1995). Sendo assim, surgia a possibilidade de que uma fração desse volume de $A L$ remanescente pudesse ser remanejada para a fibra nervosa com o fator de difusão hialuronidase, e prolongar o bloqueio da condução nervosa.

O panorama descrito por Ridenour et al. (2001) poderia parecer irrevogável quanto à contra-indicação da associação $A L$ e hialuronidase na odontologia, e assim o seria não fosse a possibilidade aventada e confirmada por Borsatti et al. (2004) e Horliana (2006). Ambos os trabalhos mostraram resultados promissores no sucesso da associação quando injetada antes do término do efeito AL. 
Para testar essa hipótese, foi realizado inicialmente um ensaio laboratorial in vivo, em que a hialuronidase (800 UTR) foi aplicada isoladamente, sessenta minutos após o bloqueio nervoso ciático de ratos com uma mistura enantiomérica (S75:R25) de bupivacaína (BORSATTI et al., 2004). Os autores encontraram um aumento na duração da analgesia induzida pelo AL.

Horliana (2006), em seu estudo, encontrou aumento $(p<0,01)$ da duração da anestesia pulpar e gengival com mepivacaína, de 28 minutos e 26 minutos, respectivamente, em comparação ao placebo, aplicando hialuronidase 75 UTR antes do término do efeito anestésico.

No presente ensaio clínico, a eleição do anestésico local considerou o tempo aproximado da realização de uma extração de terceiro molar inferior semi-incluso, de aproximadamente uma hora. Assim, o tipo de anestésico local a ser utilizado poderia ser qualquer um que tivesse duração de anestesia pulpar média de uma hora após bloqueio pterigomandibular, como a lidocaína, mepivacaína ou prilocaína, desde que associado a um vasoconstritor (JASTAK; YAGIELA, 1983; MALAMED, 2001; NAFTALIN; YAGIELA, 2002). A associação anestésica escolhida foi a mepivacaína a $2 \%$ com adrenalina 1:100.000.

A escolha do momento de injeção da hialuronidase baseou-se na duração média do efeito dessa solução anestésica local, de 60 minutos em tecido pulpar (MALAMED, 2001). Injetando-se a hialuronidase aos 40 minutos após a administração do AL, conforme estudo de Horliana (2006), no mesmo local da injeção do $\mathrm{AL}$, pela técnica de bloqueio pterigomandibular, esperava-se a redistribuição das moléculas de $\mathrm{AL}$ ainda presentes no local, objetivando prolongar o efeito anestésico. 
A determinação da dose de hialuronidase de 75 UTR utilizada neste estudo foi arbitrária (empírica) e corresponde à metade da dose utilizada por Ridenour et al. (2001) de 150 UTR, a fim de verificar se numa concentração menor ela seria suficiente para prolongar a duração de ação.

$\mathrm{O}$ volume de $\mathrm{AL}$ utilizado foi fixado de $1,8 \mathrm{~mL}$ no bloqueio do nervo alveolar inferior e 1,0 $\mathrm{mL}$ como complemento do nervo bucal. Sempre que houve necessidade de complementação anestésica durante a cirurgia (2 casos, e ambos antes da administração da hialuronidase), os pacientes deixavam de participar do estudo, devido à variação no volume de solução utilizada. Já no caso de haver falha na técnica do bloqueio, ou seja, antes do início da cirurgia, (como ocorreu em 4 sessões clínicas) pedia-se para o paciente retornar na semana seguinte para um novo atendimento.

Clinicamente, o uso de hialuronidase nessas condições se mostrou vantajoso, pois o aumento na duração anestésica pulpar e gengival proporciona mais tempo para a realização do procedimento clínico. Acredita-se que desta maneira prolongouse a duração da anestesia, sem aumentar a quantidade de AL injetado, demonstrando indiretamente que houve um remanejamento das mesmas moléculas de $A L$ que restavam no tecido e evitando, desta forma, a complementação anestésica (HORLIANA, 2006).

Embora a adrenalina e a hialuronidase pareçam ter efeitos opostos: uma impede a difusão e a outra facilita, a associação de ambos ao AL não é tão ilógica como poderia parecer. Os loci de ação desses agentes são diferentes, determinando o primeiro, maior dificuldade da entrada do fármaco na circulação, pelo seu efeito vasoconstritor local (NAFTALIN; YAGIELA, 2002), ao passo que a hialuronidase determina maior permeabilidade do tecido conjuntivo (WATSON, 1993). Pelo fato da 
hialuronidase agir sobre essas barreiras anatômicas ultra-estruturais, diminuindo a sua interferência na difusão do anestésico local, altera, portanto, a farmacocinética do agente anestésico local, ou seja, em decorrência da possibilidade de difusão também para a circulação sanguínea.

O uso de um vasoconstritor associado ao $\mathrm{AL}$ tem sido extensamente explorado na literatura e, quando devidamente indicado, propicia benefícios como aumento da duração do efeito, redução do risco de toxicidade ao $A L$, e, ainda, hemostasia local (MALAMED, 2001; NAFTALIN; YAGIELA, 2002).

Ainda é incerta a ação da hialuronidase sobre a permeabilidade capilar, mas é preciso salientar que o efeito mais importante da hialuronidase refere-se a um aumento de permeabilidade dos tecidos (STERN, 2001; WATSON, 1993). Com isso, surgiu a dúvida se a hialuronidase provocaria difusão do AL para a circulação, aumentando o risco de toxicidade. Como citado anteriormente, o estudo de Nathan et al. (1996) demonstrou, em humanos, que a hialuronidase não induziu um aumento na concentração plasmática de $\mathrm{AL}$, mas apenas antecipou esse pico de concentração (redução do $T_{\max }$ ). Esses resultados foram corroborados pelos estudos de Dempsey, Barrett e Kirby (1997), Gao e Budd (1996) e Keeler et al. (1992). Porém. não foi demonstrado para as concentrações de hialuronidase e técnica utilizados nesse estudo.

Quanto ao método de aleatorização, pode-se considerar que este estudo foi parcialmente aleatorizado, já que era previsto o cruzamento de grupo na segunda cirurgia. O lado em que foi realizada a primeira cirurgia foi escolhido de modo aleatório, como também a solução que seria utilizada primeiro (hialuronidase ou placebo). Na cirurgia realizada do outro lado, era necessária a utilização da outra 
solução diferente da primeira (em cada paciente sempre foram utilizadas as duas soluções) ou seja, estudo controlado.

Os resultados demonstraram não ter havido diferenças significativas $(p>0,01)$ para todas as variáveis: pressão arterial sistólica (gráfico 5.3), diastólica (gráfico 5.4) e média (gráfico 5.5) e freqüência cardíaca (gráfico 5.6), entre os dos grupos (hialuronidase e placebo) e ao longo das etapas clínicas. Uma possível explicação para estes resultados é que, no momento em que a hialuronidase foi injetada (no $40^{\circ}$ minuto desde o início da anestesia), a quantidade de $\mathrm{AL}$ remanescente ao redor do local de ação já estivesse reduzida e mesmo que a hialuronidase facilitasse a difusão para a corrente sanguínea, o faria em baixa concentração, demonstrado indiretamente neste estudo, não induzindo efeitos adversos. Entretanto, a constatação de baixos níveis sanguíneos do $A L$ necessitaria comprovação experimental. Não foram encontrados na literatura estudos usando o mesmo protocolo para comparação dos resultados.

Aos pacientes que possuem algum tipo de comprometimento sistêmico em que é recomendada a limitação da dose de $A L$, associado ou não a vasoconstritor, poderia ser indicada a hialuronidase, administrada antes do término do efeito de um anestésico de duração intermediária, tornando a duração prolongada. Esse protocolo seria mais interessante que a utilização de um anestésico de longa duração como, por exemplo, a bupivacaína, contra-indicada para muitos desses pacientes devido à sua grande cardiotoxicidade e neurotoxicidade (BORSATTI; TAKAOKA, 2007). Vale ressaltar que são necessários estudos de eficácia e segurança quanto à indicação da hialuronidase em cada uma das condições clínicas em que existe a limitação na quantidade de anestésico ou do vasoconstritor. 
No protocolo utilizado em oftalmologia, quando a hialuronidase foi injetada junto ao $A L$, não foram observadas alterações cardiovasculares significativas (BARR et al.,1995; GAO; BUDD, 1996; NATHAN et al., 1996; SOARES et al., 2002). Ainda, Nathan et al. (1996) discutem que embora a hialuronidase tenha alterado a farmacocinética do $\mathrm{AL}$, com aumento da concentração plasmática, esta foi considerada menor que a concentração plasmática tóxica, entretanto, faltam estudos que avaliem se esse aumento da concentração plasmática seria suficiente para induzir riscos em pacientes comprometidos sistemicamente.

Nota-se, que em ambos os grupos, a variável freqüência cardíaca apresentou uma tendência de queda ao longo do experimento, não-significativa. Houve também uma tendência $(p>0,01)$ de aumento desse parâmetro em momentos considerados de maior estresse como anestesia e luxação, mas que ainda assim foram antes do uso da hialuronidase/placebo. Ressalta-se a importância do papel do sistema nervoso autônomo na modulação da resposta cardiovascular durante o procedimento cirúrgico considerado estressante (FRABETTI; CHECCHI; FINELLI, 1992). Não foi, contudo, realizado neste estudo, qualquer método de avaliação de ansiedade ou de resposta neuro-humoral ao estresse.

O protocolo de uso de anestésico local com vasoconstritor seguido da administração isolada de hialuronidase, para essa dose e via de administração, foi considerado seguro por não promover variação hemodinâmica. 


\section{CONCLUSÕES}

O uso da hialuronidase injetada isolada, antes da regressão do efeito anestésico, mostrou-se seguro para esta dose e via de administração, por não promover variação hemodinâmica. 


\section{REFERÊNCIAS ${ }^{1}$}

Agata $\mathrm{H}$, Ichinohe $\mathrm{T}$, Kaneko $\mathrm{Y}$. Felypressin-induced reduction in coronary blood flow and myocardial tissue oxygen tension during anesthesia in dogs. Can J Anaesth 1999; 49(11):1070-5.

Ahamed S, Ahamed AO. Hyaluronidase revisited - a single injection technique for harvesting split thickness skin grafts under local anesthesia. Br J Plast Surg 2004; 57(6):589-91.

Barr J, Kirkpatrick N, Dick A, Leonard L, Hawksworth G, Noble DW. Effects of adrenaline and hyaluronidase on plasma concentrations of lignocaine and bupivacaine after peribulbar anaesthesia. Br J Anaesth 1995;75(6):692-97.

Borsatti, MA, Simonetti, MPB, Rocha, RG, Penha SS. Hyaluronidase induce longterm analgesia of the EBM S75:R25: a study in the sciatic nerve of the rat in vivo [abstract H10]. Braz Oral Res 2004;18(1):18 Suppl.

Borsatti MA, Takaoka F. Analgesia e anestesia em portadores de cardiopatias: aplicabilidade de recursos de sedação. In Cardiologia e odontologia. Uma visão integrada. Socesp - Ed. Santos $1^{\mathrm{a}}$ ed, 2007. Cap 12, p.191-207. 2007. Serrano J CV, Oliveira MCM, Lotufo RFM, Moraes RGB, Morais TMN.

Bruno E, Farronato GP, Porcellini A, Sgulmar M. Contributo clinico sullúso della mepivacaína e della lidocaína. Dental Cadmos 1987;55(19):51-8.

Brydon CW, Basler M, Kerr MB. An evaluation of two concentrations of hyaluronidase for supplementation of peribulbar anaesthesia. Anaesthesia 1995;50(11):998-1000.

Chan SK, Karmakar MK, Chui PT. Local anesthesia outside the operating room. Hong Kong Med J 2002;8(2):106-13.

Crawford M, Kerr, WJ. The effect of hyaluronidase on peribulbar block. Anaesthesia 1994;49(10):907-8.

Dempsey GA, Barret PJ, Kirby IJ. Hyaluronidase and peribulbar block. Br J Anaesth 1997;78(6):671-4.

\footnotetext{
${ }^{1}$ De acordo com o Estilo Vancouver. Abreviatura de periódicos segundo Bases de dados MEDLINE.
} 
Duran R. The effect of extracts of certain organs from normal and immunized animals on the infecting power of vaccine virus. J Exp Med 1929;50:327-40.

Farr C, Menzel J, Seeberger J, Schweigle B. Clinical pharmacology and possible applications of hyaluronidase with reference to Hylase "Dessau". Wien Med Wochenschr 1997;147(15):347-55.

Frabetti L, Checchi L, Finelli K. Cardiovascular effects of local anesthesia with epinephrine in periodontal treatment. Quintessence Int 1992;23(1):19-24.

Gao F, Budd AJ. Venous level of lignocaine and bupivacaine after peribulbar block. Anaesthesia 1996;51(12):1109-12.

Hamada S, Devys JM, Xuan TH, Ganem S, Sahel JA, Héran F. Role of hyaluronidase in diplopia after peribulbar anesthesia for cataract surgery. Ophthalmology 2005;112(5):879-82.

Hawkins JM, Moore PA. Local anesthesia: advances in agents and techniques. Dent Clin North Am 2002;46(4):719-32.

Horliana ACRT. Avaliação da duração anestésica sob a influência da hialuronidase injetada isoladamente no bloqueio pterigomandibular [Dissertação de Mestrado]. São Paulo: Faculdade de Odontologia da USP, 2006.

Hynes WL, Walton SL. Hyaluronidases of gram-positive bacteria. FEMS Microbiol Lett 2000;183(2):201-7.

Jastak JT, Yagiela, JA. Vasoconstrictors and local anesthesia: a review and rationale for use. J Am Dent Assoc 1983;107(4): 623-30.

Jowett NI, Cabot LB. Patients with cardiac disease: considerations for the dental practitioner. Br Dent J 2000;189(6):297-302.

Kallio $\mathrm{H}$, Paloheimo M, Maunuksela EL. Hyaluronidase as an adjuvant in bupivacaine-lidocaine mixture for retrobulbar/peribulbar block. Anesth Analg 2000; 91(4):934-7.

Keeler JF, Simpson KH, Ellis FR, Kay SP. Effect of addition of hyaluronidase to bupivacaine during auxillary brachial plexus block. Br J Anaesth 1992; 68(1):68-71. 
Kirby C, Eckenhoff J, Looby J. The use oh hyaluronidase with local anesthetic agents in nerve block and infiltration anesthesia. Surgery 1949;25:101.

Lewis-Smith PA. Adjunctive use of hyaluronidase in local anaesthesia. Br J Plast Surg 1986;39:554-8.

Looby J, Kirby C. Use of hyaluronidase with local anesthetic agents in dentistry. J Am Dent Assoc 1949;38:1-4.

Malamed SF. Manual de anestesia local. $4^{\mathrm{a}}$ ed. Rio de Janeiro: Guanabara Koogan; 2001.

Mantovani C, Bryant AE, Nicholson G. Efficacy of varying concentrations of hyaluronidase in peribulbar anaesthesia. Br J Anaesth 2001;86(6):876-8.

Miyachi K, Ichinohe T, Kaneko Y. Effects of local injection of prilocaine-felypressin on the myocardial oxygen balance in dogs. Eur J Oral Sci, 2003;11(4):339-45.

Naftalin LW, Yagiela JA. Vasoconstrictors: indications and precautions. Dent Clin North Am 2002;46(4):733-46.

Naguib M, Magboul MMA, Samarkandi AH, Attia M. Adverse effects and drug interactions associated with local and regional anaesthesia. Drug Safety 1998; 18(4):221-50.

Nathan N, Benrhaiem M, Lotfi H, Debord J, Rigaud G, Lachatre G et al. The role of hyaluronidase on lidocaine and bupivacaine pharmacokinetics after peribulbar blockade. Anesth Analg 1996;82(5):1060-4.

Nicoll JM, Treuren B, Acharya PA, Ahlen K, James M. Retrobulbar anaesthesia: the role of hyaluronidase. Anesth Analg 1986;65(12):1324-8.

Pell GJ, Gregory BT. Impacted mandibular third molars, classification and modified technique for removal. Dent Digest 1933;39:330-8.

Perusse R, Goulet JP, Turcotte JY. Contraindications to vasoconstrictor in dentistry: Part I. Cardiovascular diseases. Oral Surg Oral Med Oral Pathol 1992;74(5):679-97. 
Popitz-Bergez FA, Leeson S, Strichartz GR, Thalhammer JG. Relation between functional deficit and intraneural local anesthetic during peripheral nerve block: a study in the rat sciatic nerve. Anesthesiology 1995;83(3):583-92.

Prado R, Hohn AR, Albuquerque M, Gonçalves SLM. Avaliação da eficácia anestésica da lidocaína a 2\% com adrenalina 1:100.000 e mepivacaína 3\% sem vasoconstritor. Rev Bras Odontol 2000;57(1):31-3.

Quhill F, Bowling B, Packard RB. Hyaluronidase allergy after peribulbar anesthesia with orbital inflammation. J Cataract Refract Surg 2004;30(4):916-7.

Ridenour S, Reader A, Beck M, Weaver J. Anesthetic efficacy of a combination of hyaluronidase and lidocaine with epinephrine in inferior alveolar nerve blocks. Anesth Prog 2001;48(9):9-15.

Salmen S. Inhibitors of bacterial and mammalian hyaluronidase: synthesis and structure-activity relationships. Regensburg: University of Regensburg; 2003.

Sarvela J, Nikki P. Hyaluronidase improves regional ophthalmic anaesthesia with etidocaine. Can J Anaesth 1992;39(9):920-4.

Soares LF, Helayel PE, Conceição DB, Oliveira Filho GR. Bloqueio peribulbar com ME de bupivacaína S75:R25 0,5 \% e lidocaína 2\%: efeitos de adição de hialuronidase. Rev Bras Anestesiol 2002;52(4):420-5.

Spallicci MDB. Estudo clínico aleatório com grupo controle e mascaramento duplo da maturação de colo uterino pela hialuronidase em gestações a termo [Tese de Doutorado]. São Paulo: Faculdade de Medicina da USP,2002.

Stern R. Minireview on the mammalian hyaluronidases: introductory remarks. Matrix Biol 2001;20(8):497.

Watson D. Hyaluronidase. Br J Anaesth 1993;71(3):422-5.

Wynn RL. Hypertension medications and dental considerations. Gen Dent 2000; 48(2):126-31. 
APÊNDICE A - Classificação de Pell e Gregory, 1933

Classificação de Pell e Gregory

Classe I

Existe espaço suficiente entre o ramo e a distal do segundo molar para acomodação do diâmetro mesio-distal do terceiro molar.

Classe II

O espaço entre o segundo molar e o ramo da mandíbula é menor que o diâmetro mesio-distal do terceiro molar.

Classe III

O terceiro molar está no ramo da mandíbula.

A

A porção mais alta do terceiro molar está acima ou no plano oclusal.

B

A porção mais alta do terceiro molar está entre o plano oclusal e a linha cervical do segundo molar.

A mais alta porção do terceiro molar está abaixo da linha cervical do segundo molar. 
APÊNDICE B - Dados absolutos - Dados demográficos

\begin{tabular}{lccccc}
\hline Paciente & Gênero & Idade & Peso & Altura & IMC \\
1 & F & 20 & 68 & 1,65 & 24,9 \\
2 & $\mathrm{~F}$ & 25 & 63 & 1,68 & 22,3 \\
3 & $\mathrm{M}$ & 20 & 61 & 1,70 & 21,2 \\
4 & $\mathrm{~F}$ & 19 & 48 & 1,55 & 19,9 \\
5 & $\mathrm{~F}$ & 18 & 69 & 1,65 & 25,3 \\
6 & $\mathrm{~F}$ & 20 & 53 & 1,60 & 20,70 \\
7 & $\mathrm{M}$ & 19 & 78 & 1,86 & 22,54 \\
8 & $\mathrm{~F}$ & 23 & 50 & 1,49 & 22,5 \\
9 & $\mathrm{~F}$ & 23 & 50 & 1,58 & 20 \\
10 & $\mathrm{~F}$ & 35 & 72 & 1,75 & 23,5 \\
11 & $\mathrm{~F}$ & 27 & 59 & 1,60 & 23,04 \\
12 & $\mathrm{~F}$ & 24 & 54 & 1,52 & 23,3 \\
13 & $\mathrm{~F}$ & 27 & 60 & 1,68 & 21,2 \\
14 & $\mathrm{M}$ & 25 & 70 & 1,70 & 24,2 \\
15 & $\mathrm{M}$ & 23 & 72 & 1,69 & 25,2 \\
16 & $\mathrm{M}$ & 24 & 65 & 1,73 & 21,73 \\
17 & $\mathrm{M}$ & 25 & 60 & 1,68 & 21,2 \\
18 & $\mathrm{~F}$ & 20 & 63 & 1,60 & 24,6 \\
19 & $\mathrm{~F}$ & 23 & 55 & 1,60 & 21,4 \\
20 & $\mathrm{M}$ & 24 & 60 & 1,70 & 20,7 \\
\hline
\end{tabular}


APÊNDICE C - Estatística descritiva dos dados demográficos - dados demográficos

\begin{tabular}{lcccc}
\hline & Idade & Peso & Altura & IMC \\
Tamanho da amostra & 20 & 20 & 20 & 20 \\
Mínimo & 18 & 48 & 1,49 & 19 \\
Máximo & 35 & 82 & 1,86 & 25,2 \\
Amplitude Total & 17 & 34 & 37 & 6 \\
Mediana & 23 & 60,5 & 1,66 & 22 \\
Primeiro quartil (25\%) & 20 & 54,75 & 1,60 & 21 \\
Terceiro quartil (75\%) & 25 & 68,25 & 1,70 & 23,25 \\
Desvio Interquartílico & 5 & 13,5 & 10 & 2,25 \\
Média Aritmética & 23,2 & 62 & 1,65 & 22,25 \\
Variância & 14,9 & 85,1 & 72,9 & 5,1447 \\
Desvio Padrão & 3,9 & 9,2 & $\mathbf{8 , 5}$ & 2,2682 \\
Erro Padrão & 0,9 & 2,1 & 1,9 & 0,5072 \\
Coeficiente de Variação & $16,64 \%$ & $14,87 \%$ & $5,18 \%$ & $10,19 \%$ \\
Assimetria (g1) & 1,4 & 0,5 & 0,3 & 1,3399 \\
Curtose (g2) & 3,5 & $-0,2$ & 0,8 & 2,9098 \\
Média harmônica & 22,666 & 60,7416 & 164,5339 & 22,0505 \\
N (média harmônica) & 20 & 20 & 20 & 20 \\
Média geométrica & 22,922 & 61,3631 & 164,7414 & 22,1472 \\
N (média geométrica) & 20 & 20 & 20 & 20 \\
Variância (geom.) & 1,0107 & 1,0094 & 1,0012 & 1,0041 \\
Desvio-padrão (geom.) & 1,1693 & 1,1584 & 1,052 & 1,1022 \\
\hline
\end{tabular}


APÊNDICE D - Tempos cirúrgicos em valores absolutos

\begin{tabular}{lcc}
\hline \multicolumn{3}{c}{ Tempo cirúrgico em minutos* } \\
Paciente & Hialuronidase & Placebo \\
1 & 67 & 54 \\
2 & 55 & 59 \\
3 & 84 & 85 \\
4 & 50 & 51 \\
5 & 50 & 76 \\
6 & 74 & 66 \\
7 & 87 & 68 \\
8 & 62 & 66 \\
9 & 35 & 37 \\
10 & 62 & 90 \\
11 & 64 & 64 \\
12 & 51 & 80 \\
13 & 30 & 46 \\
14 & 60 & 82 \\
15 & 90 & 85 \\
16 & 60 & 83 \\
17 & 62 & 61 \\
18 & 70 & 73 \\
19 & 50 & 33 \\
20 & 55 & 68 \\
\hline
\end{tabular}

* início da anestesia local até o término da cirurgia. 


\begin{tabular}{lcc}
\hline & Hialuronidase & Placebo \\
Tamanho da amostra & 20 & 20 \\
Mínimo & 30 & 33 \\
Máximo & 90 & 90 \\
Amplitude Total & 60 & 57 \\
Mediana & 61 & 67 \\
Primeiro quartil (25\%) & 50,75 & 57,75 \\
Terceiro quartil (75\%) & 67,75 & 80,5 \\
Desvio Interquartílico & 17 & 22,75 \\
Média Aritmética & 60,9 & 66,4 \\
Variância & 237,8 & 261,6 \\
Desvio Padrão & 15,4 & 16,2 \\
Erro Padrão & 3,4 & 3,6 \\
Coeficiente de Variação & $25,32 \%$ & $24,38 \%$ \\
Assimetria (g1) & 0,1 & $-0,5$ \\
Curtose (g2) & 0,2 & $-0,4$ \\
Média harmônica & 56,7446 & 61,7059 \\
N (média harmônica) & 20 & 20 \\
Média geométrica & 58,9149 & 64,1882 \\
N (média geométrica) & 20 & 20 \\
Variância (geom.) & 1,0327 & 1,0337 \\
Desvio-padrão (geom.) & 1,313 & 1,3181 \\
\hline
\end{tabular}


APÊNDICE $F$ - Resultados da ANOVA das variáveis PS, PD, PM e FC, com 2 fatores de variação: hialuronidase $(\mathrm{H})$ e Tempo $(\mathrm{T})$

$\left(C=\right.$ conclusão; ${ }^{*}=p<0,01$ *; NS= não-significativo $)$

\begin{tabular}{|c|c|c|c|c|c|c|c|c|c|c|}
\hline \multirow[b]{2}{*}{$\begin{array}{l}\text { Fonte da } \\
\text { Variação }\end{array}$} & \multicolumn{5}{|c|}{ PS } & \multicolumn{5}{|c|}{ PD } \\
\hline & $\begin{array}{c}\text { soma } \\
\text { dos } \\
\text { quadrados }\end{array}$ & $\begin{array}{c}\begin{array}{c}\text { graus } \\
\text { de } \\
\text { liberdade }\end{array} \\
\end{array}$ & $\begin{array}{c}\text { quadra } \\
\text { do } \\
\text { médio }\end{array}$ & $F$ & C & $\begin{array}{c}\text { soma } \\
\text { dos } \\
\text { quadrados } \\
\end{array}$ & $\begin{array}{l}\text { graus de } \\
\text { liberdade }\end{array}$ & $\begin{array}{l}\text { quadrado } \\
\text { médio }\end{array}$ & $F$ & C \\
\hline $\mathrm{H}$ & 72.000 & 1 & 72.000 & 1.21 & NS & 1,1833 & 1 & 1,1833 & 0,03 & NS \\
\hline $\begin{array}{l}\text { RESÍDUO } \\
\text { I }\end{array}$ & $\begin{array}{c}35847,800 \\
8 \\
\end{array}$ & 228 & $\begin{array}{c}157,227 \\
2 \\
\end{array}$ & & & 21214,6992 & 228 & 93,0469 & & \\
\hline $\mathbf{T}$ & 2649,2 & 11 & 240,364 & 1,53 & NS & 1691,0500 & 11 & 153,7318 & 1,65 & NS \\
\hline $\mathrm{H} \times \mathrm{T}$ & 378,0001 & 11 & 34,3636 & 0,58 & NS & 125,0166 & 11 & 11,3651 & 0,32 & NS \\
\hline $\begin{array}{l}\text { RESÍDUO } \\
\text { II }\end{array}$ & $\begin{array}{c}13604,999 \\
0 \\
\end{array}$ & 228 & 59,6710 & & & 8215,3008 & 228 & 36,0320 & & \\
\hline \multirow[t]{2}{*}{$\begin{array}{l}\text { Variação } \\
\text { Total } \\
\end{array}$} & 52552,0 & 479 & & & & 31247,2500 & 479 & & & \\
\hline & \multicolumn{5}{|c|}{ PM } & \multicolumn{5}{|c|}{ FC } \\
\hline $\begin{array}{l}\text { Fonte da } \\
\text { Variação }\end{array}$ & $\begin{array}{c}\text { soma } \\
\text { dos } \\
\text { quadrados }\end{array}$ & $\begin{array}{l}\text { graus de } \\
\text { liberdade }\end{array}$ & $\begin{array}{l}\text { quadrado } \\
\text { médio }\end{array}$ & $F$ & C & $\begin{array}{c}\text { soma } \\
\text { dos } \\
\text { quadrados }\end{array}$ & $\begin{array}{l}\text { graus de } \\
\text { liberdade }\end{array}$ & $\begin{array}{l}\text { quadrado } \\
\text { médio }\end{array}$ & $\mathbf{F}$ & C \\
\hline $\mathrm{H}$ & 50,866 & 1 & 50,667 & 1,10 & NS & 655,90 & 1 & 655,90 & 10,89 & * \\
\hline $\begin{array}{l}\text { RESÍDUO } \\
\text { I }\end{array}$ & 23726,0000 & 228 & 104,0614 & & & 79556,8984 & 228 & 348,9338 & & \\
\hline $\mathbf{T}$ & 1437,0000 & 11 & 130,6364 & 1,26 & NS & 5797,1001 & 11 & 527,0091 & 1,51 & NS \\
\hline $\mathrm{H} \times \mathrm{T}$ & 136,7333 & 11 & 12,4303 & 0,27 & NS & 336,6999 & 11 & 30,091 & 0,51 & NS \\
\hline $\begin{array}{l}\text { RESÍDUO } \\
\text { II }\end{array}$ & 10536,4004 & 228 & 46,2123 & & & 13735,9014 & 228 & 60,2452 & & \\
\hline $\begin{array}{l}\text { Variação } \\
\text { Total }\end{array}$ & 35887,0000 & 479 & & & & 100082,500 & 479 & & & \\
\hline
\end{tabular}


APÊNDICE G - Valores médios de PS, desvios-padrões e erros-padrões

\begin{tabular}{l|c|c|c|c|c|c}
\hline Etapas & \multicolumn{3}{|c|}{ Hialuronidase } & \multicolumn{3}{c}{ Placebo } \\
Clínicas & \multicolumn{3}{|c|}{} & \multicolumn{3}{c}{} \\
\hline \multirow{4}{*}{$\begin{array}{c}\text { aa } \\
\text { al }\end{array}$} & Média & Desvio & Erro & Média & Desvio & Erro \\
\cline { 2 - 7 } $\mathbf{5}$ & 113,6 & 7,5908 & 1,6974 & 114,25 & 9,6729 & 2,1629 \\
\cline { 2 - 7 } inc & 115,55 & 11,7986 & 2,6382 & 113,95 & 9,4339 & 2,1095 \\
\cline { 2 - 7 } sind & 112,45 & 9,7196 & 2,1734 & 116,95 & 11,1661 & 2,4968 \\
\cline { 2 - 7 } lux & 114,7 & 12,2177 & 2,732 & 116,9 & 12,0521 & 2,6949 \\
\cline { 2 - 7 } avul & 118,95 & 10,5355 & 2,3558 & 118,05 & 13,1288 & 2,9357 \\
\cline { 2 - 7 } cur & 119,75 & 11,3085 & 2,5287 & 121,3 & 13,6192 & 3,0454 \\
\cline { 2 - 7 } sut & 120,95 & 10,4452 & 2,3356 & 122,2 & 12,5681 & 2,8103 \\
\cline { 2 - 7 } fim & 118,65 & 8,1388 & 1,8199 & 119,05 & 10,2673 & 2,2958 \\
\cline { 2 - 7 } $\mathbf{h}$ & 116,4 & 7,3942 & 1,6534 & 117,7 & 9,8894 & 2,2113 \\
\cline { 2 - 7 } $\mathbf{3 0 d}$ & 116,3 & 10,4735 & 2,3419 & 117,2 & 10,9669 & 2,4523 \\
\cline { 2 - 7 } & 118,4 & 11,5321 & 2,5787 & 115,8 & 7,068 & 1,5805 \\
\cline { 2 - 7 } & 113,75 & 8,0255 & 1,7945 & 115,4 & 6,6681 & 1,491 \\
\hline
\end{tabular}

* 5a: 5 minutos antes da anestesia; al: anestesia local; $5 \mathrm{~d}$ : 5 minutos depois da anestesia; inc: incisão; sind: sindesmotomia; lux: luxação; avul: avulsão; cur: curetagem; sut: sutura; fim: fim da cirurgia; h: aplicação da hialuronidase; 30d: 30 minutos após a aplicação da hialuronidase. 
APÊNDICE H - Valores médios de PD, desvios-padrões e erros-padrões

\begin{tabular}{l|c|c|c|c|c|c}
\hline $\begin{array}{l}\text { Etapas } \\
\text { Clínicas }\end{array}$ & \multicolumn{3}{|c|}{ Hialuronidase } & \multicolumn{3}{c}{ Placebo } \\
\hline \multirow{4}{*}{$\begin{array}{c}\text { 5a } \\
\text { al }\end{array}$} & Média & Desvio & Erro & Média & Desvio & Erro \\
\cline { 2 - 7 } 5d & 64,75 & 9,043 & 2,0221 & 65,05 & 7,1339 & 1,5952 \\
\cline { 2 - 7 } inc & 64,45 & 7,6535 & 1,7114 & 64,9 & 9,2957 & 2,0786 \\
\cline { 2 - 7 } sind & 62,95 & 7,4655 & 1,6693 & 61,75 & 9,5249 & 2,1298 \\
\cline { 2 - 7 } lux & 62,65 & 6,5476 & 1,4641 & 64,7 & 9,1657 & 2,0495 \\
\cline { 2 - 7 } avul & 67,45 & 9,2194 & 2,0615 & 66,45 & 9,1449 & 2,0449 \\
\cline { 2 - 7 } cur & 68,7 & 7,8008 & 1,7443 & 67,75 & 8,0582 & 1,8019 \\
\cline { 2 - 7 } sut & 68,35 & 8,4372 & 1,8866 & 69,35 & 8,7736 & 1,9618 \\
\cline { 2 - 7 } fim & 67,3 & 7,3133 & 1,6353 & 68,1 & 8,1943 & 1,8323 \\
\cline { 2 - 7 } $\mathbf{h}$ & 67 & 5,6008 & 1,2524 & 67,4 & 7,2213 & 1,6147 \\
\cline { 2 - 7 } 30d & 67,3 & 9,3308 & 2,0864 & 66,1 & 8,2328 & 1,8409 \\
\cline { 2 - 7 } & 66,65 & 7,1765 & 1,6047 & 67,75 & 7,426 & 1,6605 \\
\cline { 2 - 7 } & 67,5 & 7,4868 & 1,6741 & 66,9 & 5,8029 & 1,2976 \\
\hline
\end{tabular}


APÊNDICE I - Valores médios de PM, desvios-padrões e erros-padrões

\begin{tabular}{l|c|c|c|c|c|c}
\hline $\begin{array}{l}\text { Etapas } \\
\text { Clínicas }\end{array}$ & \multicolumn{3}{|c|}{ Hialuronidase } & \multicolumn{3}{c}{ Placebo } \\
\hline \multirow{4}{*}{$\begin{array}{c}\text { 5a } \\
\text { al }\end{array}$} & Média & Desvio & Erro & Média & Desvio & Erro \\
\cline { 2 - 7 } $\mathbf{5 d}$ & 84,55 & 7,8905 & 1,7644 & 86 & 8,6268 & 1,929 \\
\cline { 2 - 7 } inc & 83,1 & 9,2957 & 2,0786 & 83,55 & 10,1228 & 2,2635 \\
\cline { 2 - 7 } sind & 82,45 & 7,5007 & 1,6772 & 83,35 & 9,1091 & 2,0369 \\
\cline { 2 - 7 } lux & 81,8 & 7,5226 & 1,6821 & 84,7 & 10,9501 & 2,4485 \\
\cline { 2 - 7 } avul & 87,15 & 10,6092 & 2,3723 & 88,05 & 9,4617 & 2,1157 \\
\cline { 2 - 7 } cur & 87,75 & 8,5093 & 1,9027 & 87,7 & 8,2213 & 1,8383 \\
\cline { 2 - 7 } sut & 87,2 & 8,1667 & 1,8261 & 88,9 & 7,9927 & 1,7872 \\
\cline { 2 - 7 } fim & 86,3 & 8,1441 & 1,8211 & 86,25 & 7,426 & 1,6605 \\
\cline { 2 - 7 } $\mathbf{h}$ & 85,45 & 7,681 & 1,7175 & 86,1 & 8,2711 & 1,8495 \\
\cline { 2 - 7 } 30d & 85,5 & 10,9424 & 2,4468 & 84,3 & 7,4346 & 1,6624 \\
\cline { 2 - 7 } & 87,55 & 9,3385 & 2,0882 & 86,7 & 8,1441 & 1,8211 \\
\cline { 2 - 7 } & 84,95 & 7,9172 & 1,7703 & 85,95 & 7,0148 & 1,5686 \\
\hline
\end{tabular}


APÊNDICE J - Valores médios de FC, desvios-padrões e erros-padrões

\begin{tabular}{|c|c|c|c|c|c|c|}
\hline $\begin{array}{l}\text { Etapas } \\
\text { Clínicas }\end{array}$ & \multicolumn{3}{|c|}{ Hialuronidase } & \multicolumn{3}{|c|}{ Placebo } \\
\hline \multirow[b]{2}{*}{$5 a$} & Média & Desvio & Erro & Média & Desvio & Erro \\
\hline & 71,5 & 11,8077 & 2,6403 & 75,35 & 12,5919 & 2,8156 \\
\hline al & 75,1 & 13,5681 & 3,0339 & 74,95 & 15,5512 & 3,4774 \\
\hline \multirow{2}{*}{$\begin{array}{l}5 d \\
\text { inc }\end{array}$} & 77,1 & 13,4474 & 3,0069 & 78,7 & 15,4753 & 3,4604 \\
\hline & 77 & 13,7611 & 3,0771 & 77 & 18,4619 & 4,1282 \\
\hline \multirow{2}{*}{$\begin{array}{l}\text { sind } \\
\text { lux }\end{array}$} & 77,2 & 15,2163 & 3,4025 & 77,55 & 17,3311 & 3,8753 \\
\hline & 73,2 & 15,7567 & 3,5233 & 78,35 & 17,9481 & 4,0133 \\
\hline \multirow{2}{*}{$\begin{array}{l}\text { avul } \\
\text { cur }\end{array}$} & 71 & 14,8217 & 3,3142 & 75,7 & 16,326 & 3,6506 \\
\hline & 68,5 & 13,6748 & 3,0578 & 72,1 & 14,9944 & 3,3528 \\
\hline \multirow{2}{*}{$\begin{array}{l}\text { sut } \\
\text { fim }\end{array}$} & 67,5 & 13,2843 & 2,9705 & 69,95 & 13,5393 & 3,0275 \\
\hline & 68,6 & 12,5337 & 2,8026 & 70,65 & 13,8726 & 3,102 \\
\hline \multirow{2}{*}{$\begin{array}{l}h \\
\text { 30d }\end{array}$} & 69,2 & 12,4334 & 2,7802 & 71,6 & 13,8161 & 3,0894 \\
\hline & 66,5 & 9,8968 & 2,213 & 68,55 & 9,0872 & 2,032 \\
\hline
\end{tabular}


APÊNDICE K - Teste Tukey para a variável FC

\section{CÁlCULO do VALOR CRÍTICO DE TUKEY}

Valor do resíduo na análise de variância: 60.2452

Nível de probabilidade (5\% ou 1\%)?: 1

Número total de dados (da amostra): 480

Número de médias que serão comparadas: 2

Número de dados usados para cada média: 240

Graus de liberdade do resíduo: 228

Valor de q tabelado, (ao nível de $1 \%$,

para 2 médias e 228 graus de liberdade): 3.00

Valor crítico de Tukey calculado: 1.50306 (interpolando c/ 2 médias)

Fator de variação: hialuronidase

Hialuronidase $(\mathrm{H}): 71.86667$

Placebo (P): 74.20417

Média H - Média P: - 2,3375 > Tukey calculado (1,50306) 
APÊNDICE L - Teste Tukey para variável FC

\section{CÁlCulo do VAlor CRítico de TuKey}

Valor do resíduo na análise de variância: 60.2452

Nível de probabilidade ( $5 \%$ ou $1 \%)$ ?: 1

Número total de dados (da amostra): 480

Número de médias que serão comparadas: 24

Número de dados usados para cada média: 20

Graus de liberdade do resíduo: 228

Valor de q tabelado, (ao nível de $1 \%$,

para 24 médias e 228 graus de liberdade): 5.00

Valor crítico de Tukey calculado: 8.67793 (interpolando 120 e infinito)

PLACEBO

\begin{tabular}{|l|l|l|l|l|l|l|l|l|l|l|l|l|l|}
\cline { 3 - 15 } \multicolumn{2}{c|}{} & $\mathbf{5 a}$ & Anest & $\mathbf{5 d}$ & Inc & Sind & Lux & Avul & Curet & Sut & Fim & H & $\mathbf{3 0 d}$ \\
\cline { 2 - 16 } \multicolumn{1}{c|}{} & $\mathbf{7 1 , 5}$ & $\mathbf{7 4 , 9 5}$ & $\mathbf{7 8 , 7}$ & $\mathbf{7 7}$ & $\mathbf{7 7 , 5}$ & $\mathbf{7 8 , 3 5}$ & $\mathbf{7 5 , 7}$ & $\mathbf{7 2 , 1}$ & $\mathbf{6 9 , 9 5}$ & $\mathbf{7 0 , 6 5}$ & $\mathbf{7 1 , 6}$ & $\mathbf{6 8 , 5 5}$ \\
\hline $\mathbf{5 a}$ & $\mathbf{7 1 , 5}$ & NS & NS & NS & NS & NS & NS & NS & NS & NS & NS & NS & NS \\
\hline Anest & $\mathbf{7 5 , 1}$ & NS & NS & NS & NS & NS & NS & NS & NS & NS & NS & NS & NS \\
\hline $\mathbf{5 d}$ & $\mathbf{7 7 , 1}$ & NS & NS & NS & NS & NS & NS & NS & NS & NS & NS & NS & NS \\
\hline Inc & $\mathbf{7 7 , 0}$ & NS & NS & NS & NS & NS & NS & NS & NS & NS & NS & NS & NS \\
\hline Sind & $\mathbf{7 7 , 2}$ & NS & NS & NS & NS & NS & NS & NS & NS & NS & NS & NS & NS \\
\hline Lux & $\mathbf{7 3 , 2}$ & NS & NS & NS & NS & NS & NS & NS & NS & NS & NS & NS & NS \\
\hline Avul & $\mathbf{7 1 , 0}$ & NS & NS & NS & NS & NS & NS & NS & NS & NS & NS & NS & NS \\
\hline Curet & $\mathbf{6 8 , 5}$ & NS & NS & $*$ & NS & $*$ & $*$ & NS & NS & NS & NS & NS & NS \\
\hline Sut & $\mathbf{6 7 , 5}$ & NS & NS & $*$ & $*$ & $*$ & $*$ & NS & NS & NS & NS & NS & NS \\
\hline Fim & $\mathbf{6 8 , 6}$ & NS & NS & $*$ & NS & $*$ & $*$ & NS & NS & NS & NS & NS & NS \\
\hline H & $\mathbf{6 9 , 2}$ & NS & NS & $*$ & NS & NS & $*$ & NS & NS & NS & NS & NS & NS \\
\hline $\mathbf{3 0 d ~}$ & $\mathbf{6 6 , 5}$ & $*$ & NS & $*$ & $*$ & $*$ & $*$ & $*$ & NS & NS & NS & NS & NS \\
\hline
\end{tabular}

\section{HIALURONIDASE}

Interação substância x tempo, com valor crítico de tukey: 8.67793 .

- $\quad$ NS $p>0,01$

- * $\mathrm{p}<0,01$. 


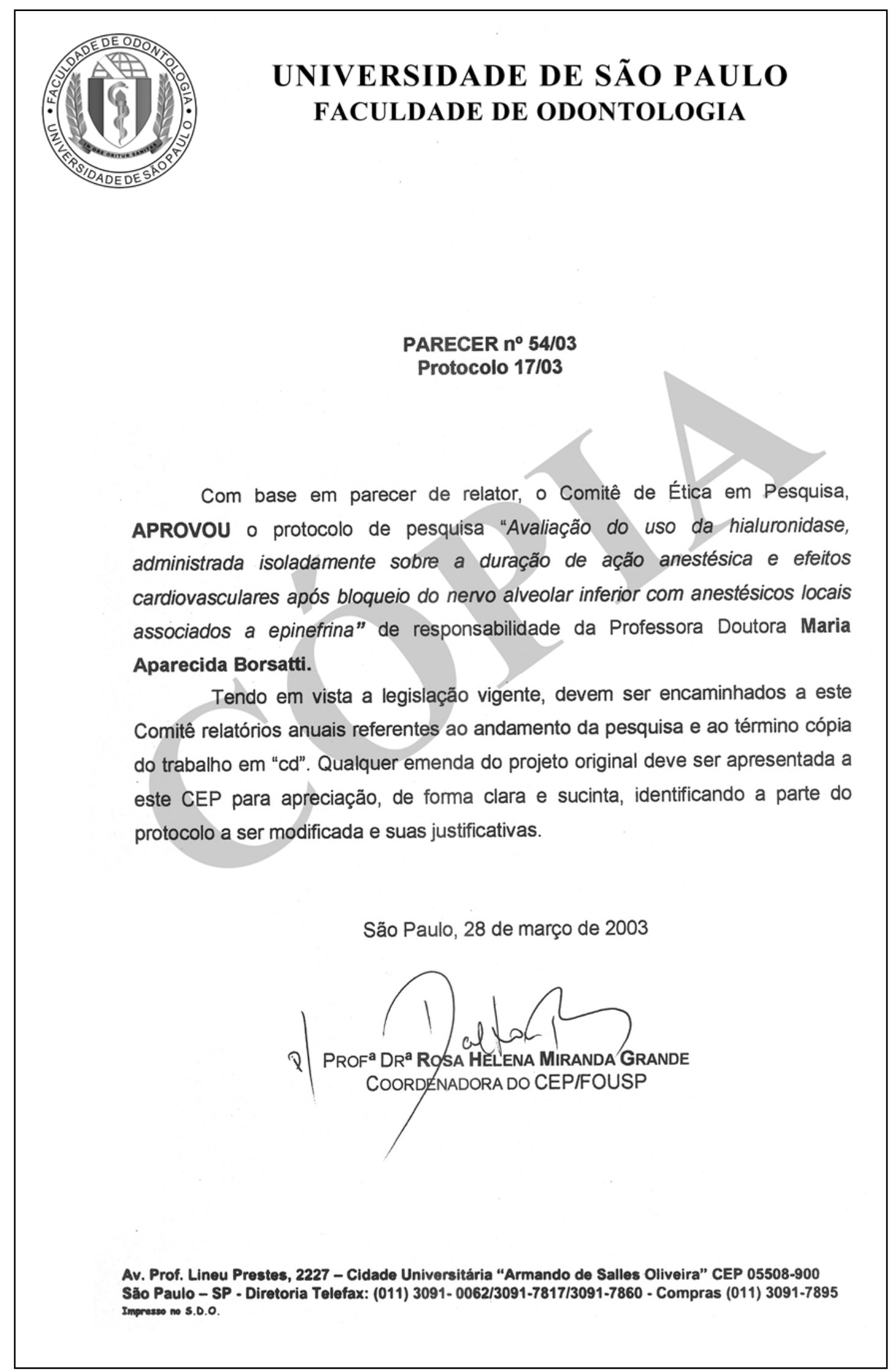




\section{TERMO DE CONSENTIMENTO LIVRE ESCLARECIDO POR ESCRITO}

Título: Avaliação do uso da hialuronidase sobre a latência e duração da anestesia e efeitos cardiovasculares do bloqueio do nervo alveolar inferior com mepivacaína associada à epinefrina.

Mestranda: Renata Martins da Silva Prado

Orientadora: Prof. Dra. Maria Aparecida Borsatti

\section{Justificativa da Pesquisa:}

Entre os anestésicos locais em uso na odontologia, a mepivacaína é considerada um anestésico de média duração anestésica, média potência. É assim, indicada principalmente para realização de extração de dentes erupcionados ou semi-inclusos e de outros tratamentos como os endodônticos ou restauradores. Quando associado à epinefrina, a duração da anestesia chega a ser de uma hora. A mepivacaína é um anestésico do tipo amida, no qual a incidência de alergia praticamente inexiste.

Sabe-se que a complementação anestésica, às vezes necessária nos bloqueios do nervo alveolar inferior, utilizando-se administrações adicionais de anestésicos pode levar a um aumento da concentração do anestésico e consequentemente induzirem os efeitos indesejáveis (alteração da pressão arterial e dos batimentos cardíacos). O uso da associação de anestésicos locais (AL) à hialuronidase (um fator que melhora a difusão dos AL nos tecidos), injetados concomitantemente, tem melhorado muito as anestesias locais na área oftalmológica, porém, em odontologia (especialmente em bloqueios do nervo alveolar inferior), o sucesso dessa associação (AL e Hialuronidase) ainda é controverso.

Como apenas uma pequena quantidade do $\mathrm{AL}$ injetado penetra no nervo $(1,6 \%)$ e o uso da hialuronidase após a injeção de AL poderia aumentar a quantidade dele dentro da fibra nervosa, aumentando a sua duração anestésica, resolvemos inicialmente injetar a solução anestésica local (mepivacaína com adrenalina) e em seguida a hialuronidase (ou água destilada) e verificar sua eficácia em aumentar a duração da anestesia.

2. Objetivos: As informações abaixo são para esclarecer e pedir a sua participação voluntária neste estudo que tem por finalidade:

1) Comparar o tempo que demora para começar o efeito da anestesia no dente e na gengiva para o anestésico utilizado;

2) Comparar o tempo de duração da anestesia local (no dente e na gengiva) entre o grupo anestésico local + hialuronidase e o grupo anestésico local sem hialuronidase (água destilada);

3) Verificar o tempo que demora para o paciente sentir dor (se houver) após a cirurgia e quando precisa tomar analgésico para o controle da dor (tempo de analgesia pós-operatória) entre o grupo anestésico local + hialuronidase e o grupo anestésico local sem hialuronidase (água destilada);

4) Verificar os efeitos na pressão arterial e freqüência cardíaca causados pela utilização do anestésico testado (mepivacaína) associado à hialuronidase ou do anestésico sem a hialuronidase (água destilada), e verificar se há alguma alteração nesses parâmetros durante e após a cirurgia.

\section{Materiais e Método}

3.1. Seleção de Voluntários: Serão selecionados 20 voluntários com pressão arterial e saúde normal, de ambos os sexos, de 18 a 45 anos de idade. Deverão apresentar necessidade de extração de dois $3^{\circ}$ molares inferiores (dente do siso), com posições semelhantes.

Os pacientes voluntários participantes da pesquisa não deverão fazer uso de qualquer outra medicação, no período de 15 dias antes da primeira consulta clínica e entre as consultas (somente a indicada pela cirurgiã-dentista). Não serão aceitas gestantes, fumantes ou pacientes alérgicos a qualquer medicamento utilizado na pesquisa ou similar. As pacientes do sexo feminino serão agendadas para as consultas logo após o período menstrual. 
3.2. Avaliação da Pressão Arterial e Freqüência Cardíaca: $A$ aferição da pressão arterial e da freqüência cardíaca (batimentos do coração) será feita através do Monitor Automático de Pressão Arterial não Invasivo (Modelo Schollar, Criticare System - USA), desde a chegada do paciente até 20 minutos do término da cirurgia.

\subsection{Avaliação do início e da duração da anestesia local:}

- Para se obter o tempo de demora para começar a anestesia e a duração do efeito anestésico na gengiva:

O paciente comunicará o momento em que não sentir mais o toque de um instrumento na sua gengiva.

- Para se obter o tempo de demora para começar a anestesia e a duração do efeito anestésico no dente (polpa): Será realizado um teste elétrico. Como será feito o teste elétrico?

Será feito com um aparelho que possui uma sonda que, encostada no dente, provoca uma sensibilidade na polpa do dente.

Em que momento será feita a aplicação do teste elétrico no dente?

A cada 2 minutos desde a anestesia local, até o momento em que o dente não responde mais ao teste. $\mathrm{E}$ após a cirurgia, a cada 10 minutos, até o retorno da sensibilidade do dente ao teste, ou seja, enquanto dura a anestesia local.

3.4. Avaliação da analgesia pós-operatória: Durante a $1^{\text {a }}$ hora após a cirurgia, a cada 10 minutos, o operador perguntará ao paciente se está sentindo alguma dor. O paciente deverá permanecer na clínica até 1 hora após a cirurgia.

Como será feita a avaliação da analgesia? A Escala Descritiva Verbal (ver abaixo), que relaciona a intensidade da dor com números de 1 (ausência de dor) a 5 (dor insuportável) será mostrada ao paciente e o valor anotado em sua ficha clínica:

\section{Escala numérica para avaliação da dor:}

\begin{tabular}{|l|l|l|l|l|}
\hline $\mathbf{1}$ & $\mathbf{2}$ & $\mathbf{3}$ & $\mathbf{4}$ & $\mathbf{5}$ \\
$\begin{array}{c}\text { Ausência } \\
\text { de dor }\end{array}$ & $\begin{array}{c}\text { Dor } \\
\text { desprezível }\end{array}$ & $\begin{array}{c}\text { Moderada/ } \\
\text { incômodo }\end{array}$ & Intensa & $\begin{array}{c}\text { Insuportável/ } \\
\text { pior dor possível }\end{array}$
\end{tabular}

Serão fornecidos aos pacientes, após cada cirurgia, 5 comprimidos de analgésico paracetamol $\left(750 \mathrm{mg}\right.$ ) (Tylenol ${ }^{\circledR}$ - JANSSEN-CILAG), orientados a tomar 1 comprimido se sentirem dor, conforme o protocolo, e fazer as anotações como explicado:

Na presença de dor, entre os 60 minutos após a cirurgia, o pesquisador anotará o momento de início de dor e sua intensidade, o momento que precisou tomar analgésico e o número de comprimidos ingeridos.

Após esse período, o paciente será dispensado, e o próprio paciente deverá fazer as anotações: anotar o momento de início de dor e sua intensidade (conforme a escala do protocolo). Anotar se houve necessidade de tomar analgésico, em que horário tomou, o total de comprimidos ingeridos e sua intensidade (conforme a escala). O paciente deverá tomar apenas a medicação prescrita no protocolo.

Observação: após aproximadamente 1 semana de pós-operatório será feito agendamento para

remoção da sutura.

\subsection{Drogas utilizadas:}

a) - Cloridrato de mepivacaína $2 \%$ associado à adrenalina 1:100.000.

b) - Hialuronidase 75 UTR/mL.

c) - Solução diluente para injetáveis (água destilada) $1 \mathrm{~mL}$.

Observação: a hialuronidase e o diluente para injetáveis receberão um código para identificação que não será divulgado ao paciente e ao pesquisador/operador até o término da pesquisa (estudo duplo-cego).

\section{Local da realização do experimento:}

Consultório odontológico no Centro de Pesquisa Clínica do Departamento de Estomatologia.

\section{Benefícios do experimento:}


- Realização de 2 cirurgias de $3^{\circ}$ molares inferiores (com indicação devido à má posição dental, ortodontia, razão protética, etc), com efeito anestésico prolongado e analgesia após a cirurgia, reduzindo a necessidade do uso de drogas analgésicas.

- Espera-se que a pesquisa traga benefícios à odontologia por fornecer informação e comprová-la por evidências clínicas da possibilidade de um protocolo de tratamento mais indolor para o paciente.

6. Desconforto ou risco esperado:

- Poderá ocorrer algum efeito estimulante decorrente do efeito do vasoconstritor;

- Inconveniente de ficar aguardando o término do efeito anestésico;

- Inconveniente de ficar aguardando uma hora de pós-operatório para avaliação da analgesia.

\section{Informações:}

O paciente voluntário terá garantia de que receberá respostas a qualquer pergunta ou esclarecimentos dos procedimentos, riscos, benefícios e outros assuntos relacionados à pesquisa.

\section{Retirada do consentimento:}

O voluntário tem a liberdade de retirar seu consentimento a qualquer momento e deixar de participar do estudo e, ainda assim poder receber os benefícios da pesquisa.

9. Os pesquisadores assumem o compromisso de proporcionar informação atualizada obtida durante o estudo, ainda que esta possa afetar a vontade do indivíduo em continuar participando.

\section{Sigilo:}

Toda e qualquer informação obtida na pesquisa será confidencial.

\section{Disponibilidade:}

Estamos à disposição a qualquer informação ou queixa por parte do paciente, podendo ligar para o seguinte telefone: 3091-7893, com Cida ou Renata.

Se ainda houver dúvidas sobre a ética da pesquisa, entre em contato com o Comitê de Ética em Pesquisa da Faculdade de Odontologia. (Avenida Lineu Prestes, 2227, Cid. Universitária, S.Paulo). 


\section{CONSENTIMENTO LIVRE ESCLARECIDO POR ESCRITO}

$\mathrm{Eu}$

RG

certifico que após ler as informações e ter sido suficientemente esclarecido(a) sobre todos os itens pelas pesquisadoras Renata Martins da Silva Prado e Prof. Dra. Maria Aparecida Borsatti (sobre a pesquisa "Avaliação do uso da hialuronidase sobre a latência e duração da anestesia e efeitos cardiovasculares do bloqueio do nervo alveolar inferior com mepivacaína associada à epinefrina"), concordo em participar de forma voluntária neste estudo. Assim, autorizo a execução do trabalho de pesquisa, exposto acima, com a minha colaboração espontânea.

Ass.paciente

$\mathrm{n}^{\circ}$ de matrícula

Renata Martins da Silva Prado

Prof. Dra. Maria Aparecida Borsatti 
ANEXO C - Ficha de Anamnese preenchida para cada paciente triado

FICHA DE ANAMNESE

\begin{tabular}{|c|c|}
\hline Universidade de São Paulo & Faculdade de Odontologia \\
\hline Nome & RG \\
\hline Endereço_ & CEP \\
\hline Bairro & Data nasc. \\
\hline
\end{tabular}

Anamnese:

1) Você está sentindo algum tipo de dor ou desconforto no momento?

2) Você está fazendo algum tratamento médico atualmente? Motivo?

3)Está tomando alguma medicação? Qual (is)?

4) Você já teve alguma reação alérgica a algum medicamento, alimento ou outro produto?

5) Você já se submeteu a anestesia local no dentista?

6) Você teve algum tipo de reação adversa a essa anestesia?

7) Você já foi submetido a alguma cirurgia ou foi hospitalizado?

8) Você já recebeu transfusão de sangue?

9) Já teve hemorragia?

10) Qual (is) destes sintomas ou doenças você tem ou já teve?

Hipertensão pneumonia

Hipotensão tuberculose

Dor de cabeça sinusite

Asma febre reumática

Bronquite gastrite

Epilepsia anemias

Problemas renais desmaio

11) Se sente cansado com freqüência? 12)Sente falta de ar?

13) Tem dificuldade de respirar quando está deitado?

14) Sente dor no peito depois de esforço ou sob tensão?

15) Quando mediu a sua PA pela última vez?

Como estava?

16) Tem alguma doença cardíaca congênita ou adquirida (ex.mal de chagas...)?

17) Tem ou teve algum sintoma ou doença não citado acima?

18) Você esta grávida?

19)Está no período menstrual?

20) Você fuma?

21)Você faz uso de bebidas alcoólicas ou outras drogas?

22) Você ingeriu bebida alcoólica nas últimas 4 horas?

Eu declaro, para todos os fins legais, que prestei esclarecimentos corretos sobre meu estado de saúde, nada omitindo no questionário que respondi.

Ass.

data

diabetes

perda de peso $(+5 \mathrm{~kg})$

ganho de peso $(+5 \mathrm{~kg})$

hepatite ou icterícia

distúrbios hepáticos

doenças venéreas

distúrbios psíquicos 


\title{
Efeitos cardiovasculares da mepivacaína com epinefrina seguida de hialuronidase: ensaio clínico parcialmente randomizado duplo-cego, controlado em cirurgias bilaterais de terceiros molares inferiores
}

\author{
THATIANA HARUMI FERRAZ*, ANNA CAROLINA RATTO TEMPESTINI HORLIANA***, MAYARA AGUILAR DIAS DE \\ BRITO**, RENATA MARTINS DA SILVA PRADO***, ISABEL PEIXOTO TORTAMANO ****, MARIA DOS PRAZERES \\ BARBALHO SIMONETTI*****, MARIA APARECIDA BORSATTI***** \\ * Aluna de Iniciação Científica da Disciplina de Clínica Integrada do Departamento de Estomatologia da Faculdade de Odontologia \\ da Universidade de São Paulo \\ ** Estagiária da Disciplina de Clínica Integrada do Departamento de Estomatologia da Faculdade de Odontologia da Universidade \\ de São Paulo. \\ *** Mestranda da Disciplina de Clínica Integrada do Departamento de Estomatologia da Faculdade de Odontologia da Universidade \\ de São Paulo. \\ **** Professora Doutora da Disciplina de Clínica Integrada do Departamento de Estomatologia da Faculdade de Odontologia da \\ Universidade de São Paulo. \\ ***** Professora Doutora da Disciplina de Farmacologia do Instituto de Ciências Biomédicas da Universidade de São Paulo.
}

\section{Resumo}

$O$ objetivo deste estudo controlado e duplocego foi avaliar, em 16 pacientes, os efeitos cardiovasculares induzidos pelo bloqueio pterigomandibular com o anestésico local $(A L)$ mepivacaína $2 \%$, associado à epinefrina, seguido da injeção de hialuronidase 75 UTR ou placebo, antes da regressão do efeito AL, para realização de cirurgia de terceiros molares inferiores bilaterais e simétricos. Os parâmetros cardiovasculares pressões sistólica (PS), diastólica $(P D)$, média $(P M)$ e freqüência cardíaca (FC) foram monitorados pelos métodos oscilométrico e fotopletismográfico, em 12 etapas clínicas. A hialuronidase injetada isoladamente depois do AL não induziu a alterações cardiovasculares significantes $(p>0,01)$, comparado ao placebo. Houve diferença significativa $(p<0,01)$ entre os valores médios da PS, PD e FC durante as etapas clínicas antes do uso da hialuronidase.

\footnotetext{
Endereço para correspondência:

Maria Aparecida Borsatti

Faculdade de Odontologia da Universidade de São Paulo

Departamento de Estomatologia - Disciplina de Clínica Integrada

Av. Prof. Lineu Prestes, 2.227 - Cidade Universitária

CEP: 05508-900 - São Paulo - SP

E-mail: maborsat@usp.br
}

Conclui-se que as alterações cardiovasculares estão relacionadas com o procedimento cirúrgico. $O$ uso de AL, seguido de hialuronidase injetada isoladamente antes da regressão do efeito anestésico, mostrou-se seguro para essa dose e via de administração.

\section{Descritores}

Hialuronoglucosaminidase. Mepivacaína. Sistema cardiovascular.

\section{INTRODUÇÃO}

Um dos adjuvantes mais utilizados em associação aos anestésicos locais é o vasoconstritor adrenalina, indicado em diversas técnicas anestésicas, para contrapor a vasodilatação inerente à maioria dos agentes anestésicos locais. Essa interação permite que a base anestésica permaneça no sítio de ação por mais tempo, pois ao diminuir o calibre dos vasos sangüíneos promove lentidão na absorção, o que induz maior duração de ação, melhora na eficácia anestésica, promove hemostasia e reduz sua toxicidade ${ }^{4}$. É o mais potente vasoconstritor em associação aos anestésicos locais, mas também é o que induz efeitos cardíacos mais intensos em elevadas concentrações, como aumento da pressão arterial sistólica, taquicardia e queda da pressão diastólica ${ }^{11}$. Os anestésicos locais de ação moderada mais utili- 
zados em associação à adrenalina são a lidocaína, mepivacaína e articaína, sendo a mepivacaína o que apresenta menor ação vasodilatadora ${ }^{3,4,10,11}$

Entre os outros adjuvantes do anestésico local, tem-se a hialuronidase, que é um agente difusor utilizado em oftalmologia, há mais de 40 anos, e que pode ser injetada junto ao AL para redução da latência, aumento da intensidade e duração anestési$\mathrm{ca}^{5,8,12,15,16}$

A associação de hialuronidase ao anestésico local tem o objetivo de aumentar a difusão deste para o nervo. A ação difusora característica da enzima hialuronidase, deve-se à despolimerização do ácido hialurônico que, sendo um componente da substância fundamental do tecido conjuntivo, diminui a viscosidade tecidual, facilitando a difusão de substâncias injetadas, sendo esta uma ação reversível $^{17,18}$.

Em outras técnicas de anestesia regional, a eficácia dessa associação ainda é controversa", assim como em odontologia na anestesia local. Quando Ridenour et al. ${ }^{15}(2001)$ realizaram injeção concomitante de lidocaína $2 \%$ com adrenalina e hialuronidase $150 \mathrm{UI} / \mathrm{ml}$ (= UTR) para bloqueio do nervo alveolar inferior em humanos, induziu ao trismo, dor e não prolongou o efeito anestésico, provavelmente devido ao AL se difundir rapidamente. Além disso, a injeção concomitante de hialuronidase e anestésico local têm demonstrado risco de ocorrer aumento de absorção sangüínea de anestésico local e outros efeitos adversos ${ }^{7,12,15}$. Esse risco é ainda maior quando a hialuronidase é injetada concomitantemente, pois nesse momento a concentração de anestésico local na proximidade do nervo e vasos sangüíneos é bastante elevada ${ }^{14}$.

Porém, uma outra forma de se utilizar a hialuronidase como adjuvante ao anestésico local, seria injetá-la isoladamente antes do término do efeito anestésico, para facilitar a difusão e remanejar as moléculas restantes de AL para o nervo e prolongar seu efeito, o que diminui a necessidade de complementação anestésica ${ }^{2}$.

Nesse protocolo, ainda há a possibilidade da hialuronidase facilitar a difusão do AL não somente para o nervo, mas também para a circulação e induzir efeitos cardiovasculares, muito embora quando injetada antes do final do efeito anestésico, a quan- tidade de AL próximo ao nervo provavelmente já esteja reduzida, diminuindo o risco de efeitos adversos. Investigações clínicas ainda não exploraram se a hialuronidase injetada antes da regressão do efeito AL induz à alterações na dinâmica cardiovascular.

\section{OBjetivos}

Avaliar os efeitos cardiovasculares (pressões sistólica, diastólica, média e freqüência cardíaca), induzidas pelo anestésico local mepivacaína $2 \%$ associada à epinefrina, seguida da injeção de hialuronidase 75 UTR ou placebo, isoladamente e de modo duplo-cego, antes da regressão do efeito AL, em cirurgia de terceiros molares inferiores.

\section{Material e Métodos}

Após a aprovação da pesquisa pelo Comitê de Ética da instituição, participaram do estudo 16 pacientes normo-reativos, de ambos os gêneros (10 mulheres e 6 homens), entre 18 e 34 anos (25,5 \pm 6,78 anos de idade), que deram seu consentimento livre e esclarecido por escrito. Apresentavam necessidade de exodontia de terceiros molares inferiores semi-inclusos, bilaterais e anatomicamente simétricos, além de história médica negativa, com pressão arterial sistólica (PS) menor que $140 \mathrm{~mm}$ $\mathrm{Hg}$, diastólica (PD) menor que $90 \mathrm{~mm} \mathrm{Hg}$ e freqüência cardíaca (FC) com valores entre 60 a 110 batimentos por minuto (bpm). Os mesmos não fizeram uso de qualquer medicação, não eram fumantes, gestantes, nem alérgicos a qualquer fármaco utilizado na pesquisa.

Os parâmetros cardiovasculares - pressão sistólica (PS), diastólica (PD), média (PM) e freqüência cardíaca (FC) - foram monitorados continuamente pelos métodos oscilométrico e fotopletismográfico, por meio do Monitor Automático - NIBP Shollar II (Criticare System ${ }^{\oplus}$ Inc., USA), durante cada cirurgia. O manguito foi posicionado no antebraço esquerdo do paciente e o dispositivo fotopletismógrafo, no dedo médio da mão direita. Após a calibragem, entre os registros obtidos foram analisados apenas um em cada etapa clínica: (E1) no $5^{\circ} \mathrm{min}$ antes da AL; (E2) no $2^{\circ} \mathrm{min}$ do $\mathrm{AL}$; (E3) $5^{\circ} \mathrm{min}$ da retirada da agulha; (E4) incisão; (E5) sindesmotomia; (E6) luxação; (E7) avulsão dental; (E8) curetagem; (E9) sutura; (E10) $5^{\circ} \mathrm{min}$ da sutura; (E11) injeção 
Ferraz TH, Horliana ACRT, Brito MAD, Prado RMS, Tortamano IP, Simonetti MPB, Borsatti MA. RPG Rev Pós Grad 2006;13(1):50-5.

da hialuronidase ou do placebo; (E12) $30^{\circ} \mathrm{min}$ após a hialuronidase.

Os pacientes foram agendados para cirurgia sempre à tarde, com intervalo mínimo de duas semanas, e atendidos sempre pelo mesmo operador. As pacientes do gênero feminino sempre foram atendidas na semana seguinte à menstruação. Para anestesia local, utilizou-se $1,8 \mathrm{ml}$ (um tubete) de cloridrato de mepivacaína $2 \%$ com adrenalina 1:100.000 (Mepiadre ${ }^{\circledR}$, DFL, Rio de Janeiro, Brasil), injetada pela técnica indireta de bloqueio dos nervos alveolar inferior e lingual (bloqueio petrigomandibular) com aspirações prévias a uma velocidade de $1,0 \mathrm{ml} /$ min. Foi feita complementação anestésica com 0,9 $\mathrm{ml}$ pela técnica infiltrativa para o nervo bucal. A duração de ação média em tecido pulpar da mepivacaína 2\% com adrenalina é de 60 minutos $\left(\right.$ Malamed $^{10}$, 2001). Como a hialuronidase ou o placebo deveriam ser injetados antes da regressão do efeito anestésico, então, estes foram injetados aos 40 minutos do início do efeito anestésico em tecido pulpar. Para determinar esse momento, a duração da anestesia pulpar foi avaliada por meio da resposta dolorosa ao estímulo elétrico com aparelho Pulptester Vitality Scanner (Analytic, USA).
A hialuronidase e o placebo foram injetados de modo duplo-cego, utilizando a mesma técnica anestésica com aspiração prévia. A solução de hialuronidase (75 UTR) (grupo experimental) e o placebo (solução salina) (grupo controle) foram preparados, envasados em cartuchos de $1,0 \mathrm{ml}$ e codificados pela Apsen Farmacêutica S/A.

Para a análise estatística dos valores médios das variáveis PS, PD, PM e FC, foi realizada análise de variância (ANOVA) com dois fatores de variação: hialuronidase $(\mathrm{H})$ e tempo $(\mathrm{T})$ (Tabela 1).

\section{Resultados}

Para todas as variáveis PS, PD, PM e FC, os valores médios obtidos não diferiram $(\mathrm{p}>0,01)$ entre os grupos com hialuronidase e placebo (Tabela 1). Também não houve diferença significativa entre os valores médios na interação entre os fatores hialuronidase e tempo (H x T). Com exceção da PM, houve diferença significativa $(\mathrm{p}<0,01)$ entre os valores médios da PS, $\mathrm{PD}$ e FC observado no fator tempo, ou seja, diferiram entre as etapas clínicas. Foi realizado para essas variáveis o teste auxiliar de Tukey para o fator tempo e os resultados estão exibidos nos Gráficos 1 a 4.

\begin{tabular}{|c|c|c|c|c|c|c|c|c|c|c|}
\hline \multicolumn{11}{|c|}{$\begin{array}{l}\text { Tabela } 1 \\
\text { Resultados da ANOVA das variáveis PS, PD, PM e FC, com } 2 \text { fatores de variação: hialuronidase }(H) \text { e tempo }(\mathrm{T}) \\
\qquad\left({ }^{*}=\mathrm{p}<0,01 ; \mathrm{NS}=\text { não significante }\right) .\end{array}$} \\
\hline & \multicolumn{5}{|c|}{\begin{tabular}{|c|} 
PS \\
\end{tabular}} & \multicolumn{5}{|c|}{ PD } \\
\hline $\begin{array}{l}\text { Fonte da } \\
\text { Variação }\end{array}$ & $\begin{array}{l}\text { Soma dos } \\
\text { Quadrados }\end{array}$ & $\begin{array}{l}\text { Graus de } \\
\text { liberdade }\end{array}$ & $\begin{array}{c}\text { Quadrado } \\
\text { médio }\end{array}$ & $\mathrm{F}$ & Conclusão & $\begin{array}{l}\text { Soma dos } \\
\text { Quadrados }\end{array}$ & $\begin{array}{l}\text { Graus de } \\
\text { liberdade }\end{array}$ & $\begin{array}{l}\text { Quadrado } \\
\text { médio }\end{array}$ & $\mathrm{F}$ & Conclusão \\
\hline $\mathrm{H}$ & 0,6 & 1 & 0,6 & 0,0 & NS & 15,8 & 1 & 15,8 & 0,3 & NS \\
\hline Residuo I & $31.100,0$ & 30 & $1.036,6$ & & & $14.463,3$ & 30 & 482,1 & & \\
\hline$T$ & $2.728,5$ & 11 & 248,0 & 5,5 & * & $1.702,1$ & 11 & 154,7 & 4,4 & * \\
\hline $\mathrm{HXT}$ & 323,8 & 11 & 29,4 & 0,6 & NS & 223,2 & 11 & 20,2 & 0,5 & NS \\
\hline Resíduo II & $14.799,0$ & 330 & 44,8 & & & $11.368,4$ & 330 & 34,4 & & \\
\hline \multirow[t]{2}{*}{$\begin{array}{l}\text { Variação } \\
\text { total }\end{array}$} & $48.952,0$ & 383 & & & & $27.773,0$ & 383 & & & \\
\hline & \multicolumn{5}{|c|}{ PM } & \multicolumn{5}{|c|}{ FC } \\
\hline $\begin{array}{l}\text { Fonte da } \\
\text { Variação }\end{array}$ & $\begin{array}{l}\text { Soma dos } \\
\text { Quadrados }\end{array}$ & $\begin{array}{l}\text { Graus de } \\
\text { liberdade }\end{array}$ & $\begin{array}{c}\text { Quadrado } \\
\text { médio }\end{array}$ & $\mathrm{F}$ & Conclusão & $\begin{array}{l}\text { Soma dos } \\
\text { Quadrados }\end{array}$ & $\begin{array}{l}\text { Graus de } \\
\text { liberdade }\end{array}$ & $\begin{array}{l}\text { Quadrado } \\
\text { médio }\end{array}$ & $F$ & Conclusão \\
\hline $\mathrm{H}$ & 16,0 & 1 & 16,0 & 0,0 & NS & 734,4 & 1 & 734,4 & 0,3 & NS \\
\hline Residuo I & $16.914,0$ & 30 & 563,8 & & & $74.216,0$ & 30 & $2.473,8$ & & \\
\hline$T$ & $1.322,5$ & 11 & 120,2 & 2,9 & NS & $5.198,8$ & 11 & 472,6 & 14,1 & $\star$ \\
\hline HXT & 188,0 & 11 & 17,1 & 0,4 & NS & 250,0 & 11 & 22,7 & 0,6 & NS \\
\hline Resíduo II & 16,0 & 1 & 16,0 & 0,0 & NS & 734,4 & 1 & 734,4 & 0,3 & NS \\
\hline $\begin{array}{l}\text { Variação } \\
\text { total }\end{array}$ & $16.914,0$ & 30 & 563,8 & & & $74.216,0$ & 30 & $2.473,8$ & & \\
\hline
\end{tabular}




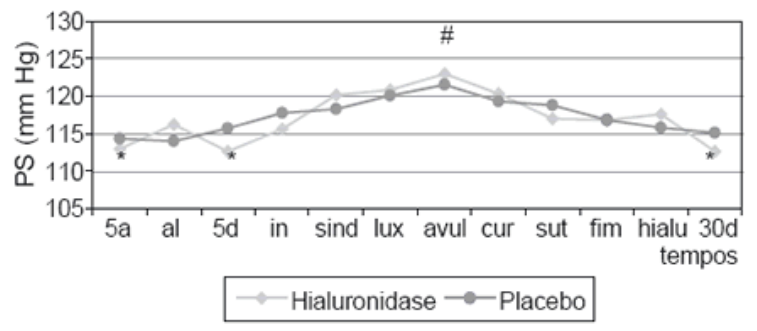

Gráfico 1 - Valores médios da PS com a mepivacaína associada à epinefrina seguida de hialuronidase ou placebo, onde $\mathrm{p}<0,01$ entre * e \# ou NS = não significativo.

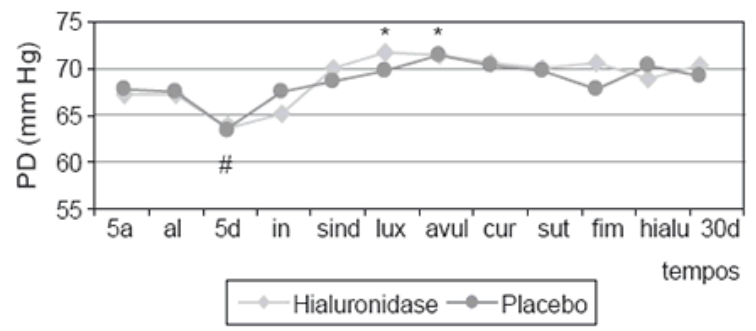

Gráfico 2 - Valores médios da PD com a mepivacaína associada à epinefrina seguida de hialuronidase ou placebo, onde $\mathrm{p}<0,01$ entre * e \# ou NS = não significativo.

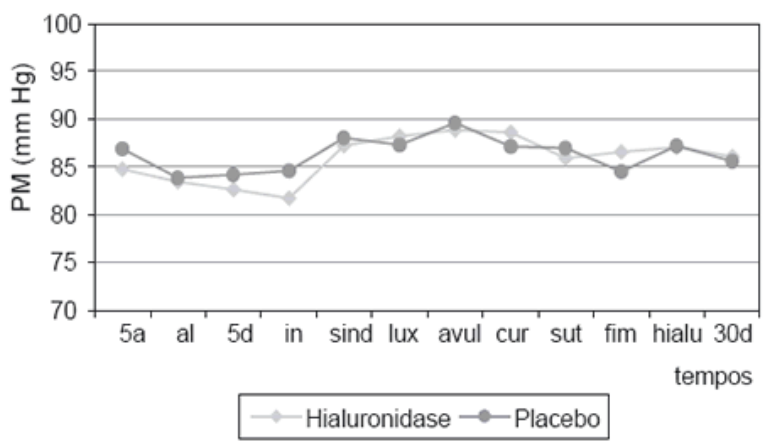

Gráfico 3 - Valores médios da PM com a mepivacaína associada à epinefrina seguida de hialuronidase ou placebo, onde $\mathrm{p}<0,01$ entre * e \# ou NS = não significativo.

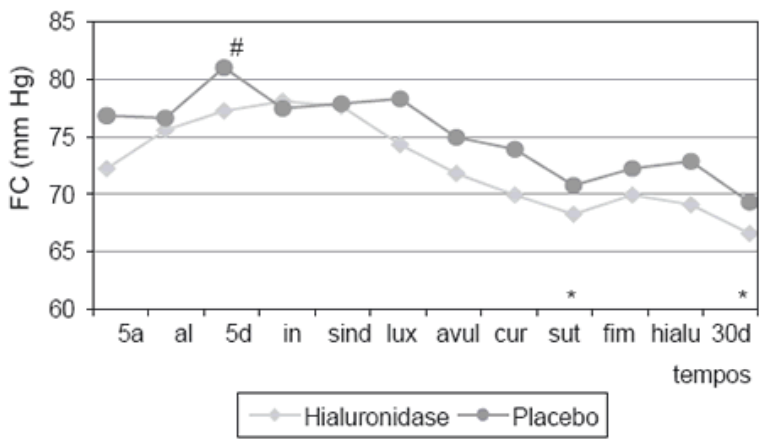

Gráfico 4 - Valores médios da $\mathrm{FC}$ com a mepivacaína associada à epinefrina seguida de hialuronidase ou placebo, onde $p<0,01$ entre * e \# ou NS = não significativo.

\section{Dıscussāo}

Os resultados mostraram que as alterações cardiovasculares induzidas pelo anestésico local, seguido de hialuronidase ou placebo, não mostraram diferenças significativas (Tabela 1) para nenhum dos parâmetros analisados. Uma possível explicação para esses resultados é que, no momento em que a hialuronidase foi injetada $\left(50^{\circ}\right.$ minuto da anestesia), a quantidade de AL remanescente ao redor do local de ação já estivesse reduzida e mesmo que a hialuronidase facilitasse a difusão para a corrente sangüínea, o faria em baixa concentração, não induzindo efeitos adversos. Entretanto, a possibilidade de haver baixo nível sanguíneo nesse protocolo necessita de comprovação experimental.

No protocolo muito utilizado em oftalmologia, quando a hialuronidase foi injetada junto ao AL, houve aumento da sua concentração plasmática, demonstrado por Barr et al. ${ }^{1}$ (1995), Nathan et al. ${ }^{12}$ (1996) e Gao e Budd $^{7}$ (1996). Mesmo assim, não foram observadas alterações cardiovasculares significantes. Nathan et al. ${ }^{12}$ (1996) discutem que embora a hialuronidase tenha alterado a farmacocinética do AL, com aumento da concentração plasmática, esta foi considerada menor que a concentração plasmática tóxica. Para bloqueio peribulbar, Soares et al. ${ }^{17}$ (2002) também não observaram alterações significativas na pressão arterial e FC ao injetar concomitantemente bupivacaína e lidocaína com hialuronidase comparado ao controle (sem hialuronidase).

Ainda é incerta a ação da hialuronidase sobre a permeabilidade capilar, mas é preciso salientar que o efeito mais importante refere a um aumento de permeabilidade dos tecidos ${ }^{17,18}$.

Foi demonstrado em nervo ciático de rato, com lidocaína marcada radiativamente, que a fração intraneural de AL capaz de bloquear a condução nervosa é muito pequena - apenas $1,6 \pm 0,12 \%$ da dose injetada - e o restante fica nas proximidades da fibra nervosa e se difunde para tecidos adjacentes ${ }^{13}$. Sendo assim, surgia a possibilidade de que uma fração desse volume de AL remanescente pudesse ser remanejada para a fibra nervosa, com o fator de difusão hialuronidase, e prolongar o bloqueio da condução nervosa. A hipótese de que se a hialuronidase fosse injetada antes da regressão do efeito anestésico, a fim de remanejar uma fração das moléculas de AL ao redor do feixe nervoso, prolongando a duração 
do bloqueio nervoso, foi demonstrada em nervo ciático de rato $^{2}$.

Entretanto, num outro protocolo, quando a hialuronidase 150 UTR foi injetada concomitante à lidocaína, com adrenalina para bloqueio pterigomandibular, ocorreu trismo muscular e dor ao invés de melhorar a qualidade do bloqueio nervoso ${ }^{14}$, possivelmente devido à ação da hialuronidase em facilitar a difusão do $\mathrm{AL}$ para tecidos adjacentes, mesmo com adrenalina associada que poderia retardar a passagem do anestésico do local de ação para a corrente sanguínea e outros tecidos. Esses efeitos adversos não foram observados no presente estudo, provavelmente porque foi utilizada a metade da concentração de hialuronidase (75 UTR) e injetada antes do término do efeito anestésico, como em outro estudo ${ }^{2}$.

A hialuronidase pode ser associada à solução de AL com ${ }^{9}$ ou sem adrenalina ${ }^{5,12,15}$, como utilizada em outras áreas da medicina. A associação desses dois adjuvantes, a adrenalina e a hialuronidase, não é tão ilógica como poderia parecer, porquanto os locos de ação dos agentes são diferentes, determinando a primeira maior dificuldade da entrada do fármaco na circulação geral, pelo seu efeito vasoconstritor local ${ }^{11}$, ao passo que a hialuronidase determina maior permeabilidade do tecido conjuntivo $^{17,18}$. O uso de um vasoconstritor associado ao AL tem sido intensamente explorado na literatura, sendo sempre recomendado quando devidamente indicado, por propiciar benefícios como aumento da duração, redução do risco de toxicidade do $\mathrm{AL}$ e hemostasia local ${ }^{10,11}$.

Neste estudo, também não houve diferença significativa entre os valores médios das variáveis cardiovasculares na interação entre o fator tratamento (hialuronidase e placebo) e o fator tempo (etapas clínicas). Entretanto, como mostra a Tabela 1 , houve diferença significativa $(\mathrm{p}<0,01)$ entre os valores médios de PS, PD e FC entre os tempos analisados (etapas clínicas), independente da presença de hialuronidase. O maior valor médio de PS foi observado durante a luxação dental que diferiu ( $\mathrm{p}<0,01)$ com o período basal antes do AL e o $5^{\circ} \mathrm{min}$ após o mesmo, antes da cirurgia e com os 30 min após a injeção da hialuronidase ou placebo (Gráfico 1). Com a PD, também houve elevação
( $\mathrm{p}<0,01)$ no momento da luxação e da avulsão comparada ao $5^{\circ} \mathrm{min}$ após anestesia (Gráfico 2). A PM permaneceu estável durante todo o procedimento (Gráfico 3). O maior valor médio de FC foi no $5^{\circ} \mathrm{min}$ depois da $\mathrm{AL}$ seguido de redução, diferindo $(\mathrm{p}<0,01)$ com o momento da sutura e a etapa final (30 min depois da hialuronidase ou placebo) (Gráfico 4). Embora tenha sido observada diferença estatisticamente significante nesses parâmetros, clinicamente não foi relatada nenhuma sintomatologia. Nota-se que os valores mais elevados ocorreram no procedimento cirúrgico mais estressante, ou seja, luxação e avulsão. Contudo, não foi realizado neste estudo nenhum método de avaliação de ansiedade.

Frabetti et al. ${ }^{6}$ (1992) obtiveram resultado de FC diferente deste estudo. Em vez de queda da FC, houve aumento significativo durante o procedimento periodontal invasivo, realizado com mepivacaína com adrenalina comparado com o não invasivo. Os autores discutem a possibilidade de elevação catecolaminas endógenas induzido pelo estresse. Quando utilizaram mepivacaína associada à adrenalina para cirurgia de terceiros molares inferiores, não observaram variação na dinâmica cardiovascular ${ }^{3}$.

Como pode ser observado, houve alteração cardiovascular durante o procedimento cirúrgico com a mepivacaína com adrenalina estatisticamente significante, mas não clinicamente, antes da injeção de hialuronidase. O protocolo de uso de $\mathrm{AL}$ com vasoconstritor seguido da administração isolada de hialuronidase, para essa dose e via de administração foi considerado seguro por não promover variação hemodinâmica ou qualquer efeito adverso.

\section{Conclusoes}

$\mathrm{O}$ uso de AL, seguido de hialuronidase injetada isolada antes da regressão do efeito anestésico, mostrou-se seguro para essa dose e via de administração. As alterações cardiovasculares estão relacionadas com as etapas clínicas.

\section{Agradecimentos}

À agência de fomento FUNDECTO e à Apsen Farmacêutica S/A pelo fornecimento da hialuronidase. 


\section{Abstract}

\section{Cardiovascular effects of mepivacaine with epinephrine followed by hyaluronidase: a double- blind controlled partially randomized clinical trial in bilateral lower third molar surgery}

The purpose of this controlled and double-blind trial was to evaluate the cardiovascular effects induced by pterigomandibular block of local anesthetic (LA) $2 \%$ mepivacaine with epinephrine, followed by injection of hyaluronidase $75 \mathrm{IU}$ or placebo (solvent) before the regression of the anesthetic effect, on symmetric bilateral lower third molar surgery in 16 outpatients. The cardiovascular parameters systolic (SP), diastolic (DP) and mean (MP) pressures and heart rate $(H R)$ were monitored by oscillometric and photopletismographic methods in 12 clinical steps of the procedure. The plain hyaluronidase injected after LA didn't induce significant cardiovascular changes $(p>0.01)$ when compared to placebo. There were significant differences $(p<0.01)$ among the mean values of $S P$, $D P$ and HR during clinical steps mainly before the use of hyaluronidase. It is possible to conclude that the cardiovascular changes occurred on account of the surgical procedure. The use of LA followed by plain hyaluronidase injected before the regression of anesthetic effect shows to be safe for this dose and way of administration.

\section{Descriptors}

Hyaluronoglucosaminidase. Mepivacaine. Cardiovascular system.

\section{ReferênCIAS Bibliográficas}

1. Barr J, Kirkpatrick N, Dick A, Leonard L, Hawksworth G, Noble DW. Effects of adrenaline and hialuronidase on plasma concentrations of lignocaine and bupivacaine after peribulbar anaesthesia. Br J Anaesth 1995;75(6):692-697.

2. Borsatti MA, Simonetti MPB, Rocha RG, Penha SS. Hyaluronidase induce long-term analgesia of the EBM S75:R25: a study in the sciatic nerve of the rat in vivo [abstract $\mathrm{H} 10$ ]. Pesqui Odontol Bras 2004;18(1): 18.

3. Bruno E, Farronato GP, Porcellini A, Sgulmar M. Contributo clinico sullúso della mepivacaina e della lidocaína. Dental Cadmos 1987;55(19):51-8.

4. Chan SK, Karmakar MK, Chui PT. Local anesthesia outside the operating room. Hong Kong Med J 2002;8(2):1063.

5. Crawford M, Kerr WJ. The effect of hyaluronidase on peribulbar block. Anaesthesia 1994;49(10):907-8.

6. Frabetti L, Checchi L, Finelli K. Cardiovascular effects of local anesthesia with epinephrine in periodontal treatment. Quintessence Int 1992;23(1):19-24

7. Gao F, Budd AJ. Venous level of lignocaine and bupivacaine after peribulbar block. Anaesthesia 1996;51 (12):1109-12.

8. Kallio H, Paloheimo M, Maunuksela EL. Hyaluronidase as an adjuvant in bupivacaine-lidocaine mixture for retrobulbar/peribulbar block. Anesth Analg 2000;91(4):934-7.

9. Keeler JF, Simpson KH, Ellis FR, Kay SP. Effect of addition of hyaluronidase to bupivacaine during axillary brachial plexus block. Br J Anaesth 1992;68(1):68-71.
10. Malamed SF. Manual de anestesia local. $4^{x}$ ed. Rio de Janeiro: Guanabara Koogan; 2001.

11. Naftalin LW; Yagiela JA. Vasoconstrictors: indications and precautions. Dent Clin North Am 2002;46(4):733-46.

12. Nathan N, Benrhaiem, M, Lotfi H, Debord J, Rigaud G, Lachatre $\mathrm{G}$ et al. The role of hyaluronidase on lidocaine and bupivacaine pharmacokinetics after peribulbal blockade Anesth Analg 1996;82(5):1060-4.

13. Popitiz-Bergez FA, Leeson S, Strichartz GR, Thalhammer JG. Relation between functional deficit and intraneural local anesthetic during peripheral nerve block. Anesthesiology $1995 ; 83(3): 583-92$.

14. Ridenour S, Reader A, Beck M, Weaver J. Anesthetic efficacy of a combination of hyaluronidase and lidocaine with epinephrine in inferior alveolar nerve blocks. Anesth Prog 2001;48(9):9-15.

15. Sarvela J, Nikki P. Hyaluronidase improves regional ophthalmic anaesthesia with etidocaine. Can J Anaesth 1992;39(9):920-4.

16. Soares LF, Helayel PE, Conceição DB, Oliveira Filho GR Bloqueio peribulbar com ME bupivacaína S75:R25 0,5\% e lidocaína $2 \%$ : efeitos de adição de hialuronidase. Rev Bras Anestesiol 2002;52(4):420-5.

17. Stern R. Minireview on the mammalian hialuronidases: introductory remarks. Matrix Biol 2001;20(8):497.

18. Watson D. Hyaluronidase. Br J Anaesth 1993;71(3):422-5.

Recebido em 12/09/2005 Aceito em 16/12/2005 